\title{
Systemic Effects of Growth Hormone in Growth Hormone Deficient Adults: A Meta-Analysis of 48 Prospective Studies
}

\author{
Alexander W. Pastuszak*, Win Shun Lai ${ }^{*}$, Mohit Khera, Larry I. Lipshultz \\ Scott Department of Urology, Baylor College of Medicine, Houston, USA \\ Email: "larryl@bcm.edu
}

Received March 27, 2012; revised May 10, 2012; accepted May 18, 2012

\begin{abstract}
Introduction: The use of growth hormone (GH) treatment in GH deficiency (GHD) continues to increase. However, individual controlled trials of the efficacy and safety of GH have involved relatively few patients and yielded variable results. We seek to analyze the overall effect of GH treatment on various parameters by performing a contemporary meta-analysis of the efficacy and safety of GH administration. Methods: Meta-analysis of 48 blinded, placebo controlled, randomized clinical studies of GH treatment in GHD adults published up to June 2011 was performed. Analyzed variables included anthropomorphic measurements (waist-hip ratio (WHR), lean body mass (LBM)/fat free mass (FFM), trunk fat (TrF), total body water (TBW), fat mass (FM), and body mass index (BMI)); cardiovascular (CV) parameters (systolic/diastolic blood pressure (SBP, DBP), heart rate (HR), stroke volume (SV), LDL, HDL, total cholesterol (TChol), triglycerides (TG), apolipoprotein B (ApoB), C-reactive protein (CRP)); and diabetes parameters (fasting insulin and glucose, hemoglobin A1c (HgbA1c)). Effect sizes (ES) were used to determine significance and weighted mean differences between GH and control were used to quantify size of effect. Results: 2231 adults with growth hormone deficiency were included. Significant beneficial changes resulting from GH administration were observed in the following variables: anthropomorphic-WHR, FM, LBM, FFM, TBW; cardiovascular-LDL, HDL, TChol, ApoB, CRP; significant adverse changes were seen in diabetic parameters - fasting insulin, fasting glucose, and HgbAlc. Compared to prior meta-analyses, larger ESs were observed for LDL, HDL, total cholesterol, fasting insulin and fasting glucose levels. Conclusions: GH administration in GHD adults results in improvement in anthropomorphic parameters, as well as CV parameters, but with worsening of diabetes markers. Data on long-term safety, including on CV effects and malignancy, as well as data assessing the role of GH replacement in combination with testosterone replacement continue to be sparse.
\end{abstract}

Keywords: Growth Hormone; Growth Hormone Deficiency; Meta-Analysis; Sex Steroids

\section{Introduction}

The use of growth hormone $(\mathrm{GH})$ for the treatment of growth hormone deficiency (GHD), a form of hypopituitarism, continues to increase. However, most studies assessing the efficacy and safety of GH involve relatively few patients. Growth hormone deficiency in adults is associated with an increased mortality rate [1,2]. Previous studies have shown that GHD affects numerous health parameters including anthropomorphic and cardiovascular $(\mathrm{CV})$ parameters, glucose and insulin sensitivity, and overall quality of life [3]. In addition, GH use by individuals without GHD continues, though no controlled studies are available to assess the effects in this setting, despite reports of deleterious effects of $\mathrm{GH}$ and/or anabolic steroids in these individuals [4-7].

\footnotetext{
"These authors contributed equally to the preparation of this manuscript. "Corresponding author.
}

Clinical trials have shown that GH therapy improves body fat parameters in the GHD population through an increase in lean body mass and a decrease in serum lipids, with variable effect sizes on these parameters observed between studies [8]. While this variability may be attributable to differences in the degree of GH deficiency, GH dose, therapy duration, sample size and/or composition, further evaluation in the form of additional controlled studies or meta-analyses is needed to clarify these points. Meta-analyses evaluating the effects of GH therapy are available, although numerous additional controlled studies have been published since the last significant report [9-12]. Moreover, recent studies have begun exploring the synergistic role of GH therapy in combination with androgen therapy in the healthy elderly population, which is likely to have future impact on the care of this population $[13,14]$. Thus, in light of the growing use of GH therapy and the addition of numerous controlled 
studies to the peer-reviewed literature, we performed a comprehensive, contemporary meta-analysis of the efficacy and safety of GH administration in GHD adults through a systematic review of blinded, randomized, placebo-controlled studies assessing GH efficacy and safety.

\section{Materials and Methods}

\subsection{Data Sources and Searches}

We searched the Medline (Ovid), Biosis, and EMBASE electronic databases from their years of inception to June 2011 for reports containing the following keywords: growth hormone $(G H)$, therapy, treatment, and growth hormone deficiency. The search strategy was limited by study design to include only adults (19+ years old) in randomized, placebo-controlled clinical trials.

\subsection{Study Selection}

Inclusion of candidate studies by two of the authors (AWP, WSL) was based on the ability of the abstract and then the actual study to meet the inclusion criteria. We identified 45 randomized, blinded, placebo-controlled trials (RBPCTs) involving patients 19 years or older with GHD corresponding to $\mathrm{GH}$ levels $<5 \mu \mathrm{g} / \mathrm{L}$ after stimulation testing using insulin and/or arginine [13-64], as recommended by the consensus guidelines for the diagnosis and treatment of adults with GHD [15] and also included 3 crossover studies that had been utilized in a prior meta-analysis for comparison [9,18,51,60] (Figure 1).

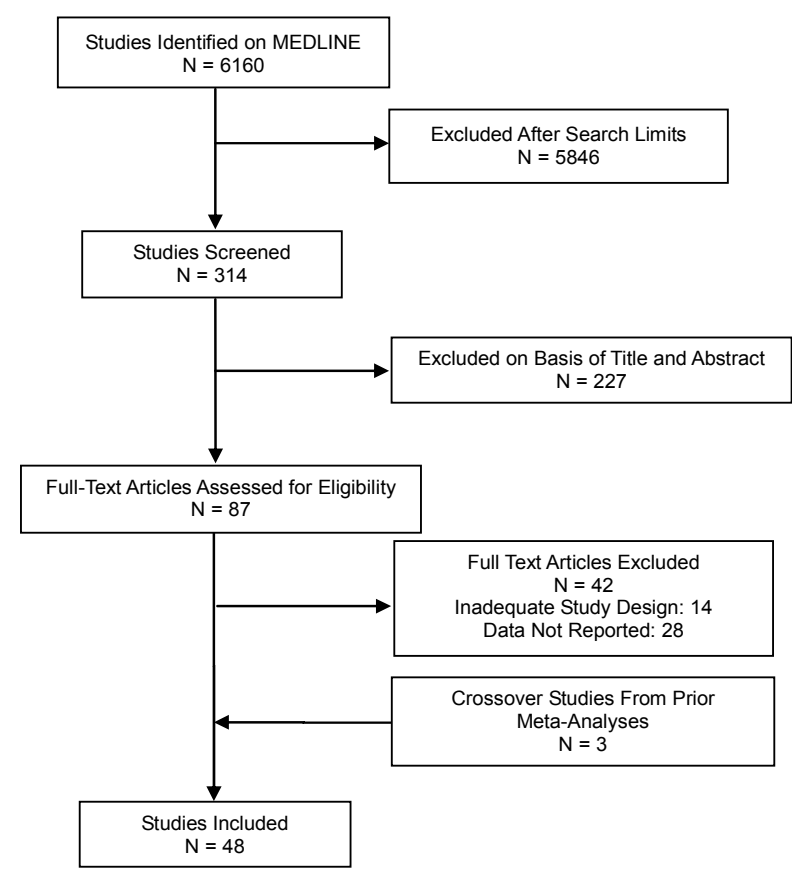

Figure 1. Identification of studies for inclusion in metaanalysis.
We also identified 2 RBPCTs assessing the effects of testosterone (T) and GH in order to compare these variables directly $[13,14]$. This study targeted variables which represent the effects of $\mathrm{GH}$ on anthropomorphic and $\mathrm{CV}$ parameters and have been frequently reported in prior studies examining the effects of $\mathrm{GH}$ : insulin-like growth factor 1 (IGF-1), insulin-like growth factor binding protein 3 (IGFBP3), waist-to-hip ratio (WHR), lean body mass (LBM), fat free mass (FFM), trunk fat $(\mathrm{TrF})$, total body water (TBW), fat mass (FM), body mass index (BMI), diastolic blood pressure (DBP), systolic blood pressure (SBP), heart rate (HR), stroke volume (SV), triglycerides (TG), high-density lipoprotein (HDL), lowdensity lipoprotein (LDL), total cholesterol (TChol), apolipoprotein B (ApoB), C-reactive protein (CRP), E (Early (diastolic))/A (late, (Atrial) filling) ratio (EAR), fractional shortening (FS), left ventricular mass (LVM), fasting glucose, fasting insulin, and hemoglobin A1c (HgbA1c).

\subsection{Data Extraction and Quality Assessment}

Summary data reflecting net effects on each variable studied from each report were extracted by a single author (WSL) into a standard form and included number of subjects, subject age, sex, cause of GHD, GHD diagnostic modality, GH dose, duration of GH therapy, GH dosing frequency, adverse effects, study design, randomization method, blinding, and statistical methods, outcome measures, subjects lost to follow-up, and baseline and follow-up means and standard deviations (SD) for each variable.

\subsection{Data Synthesis and Analysis}

For primary analyses of outcome measures, we calculated standardized effect sizes (ES) using Hedges' $g$ via a random-effects model for each trial, since such a model incorporates statistical heterogeneity and provides a more conservative estimate of pooled effect size than a fixedeffects model [65]. The ES was calculated as the mean difference (GH minus placebo) in the changes (follow-up minus baseline) for each outcome measure divided by the estimated variance of changes in the two groups, and weighted by the reciprocal of the variance. The variance-weighted mean difference (WMD) was calculated for each variable in order to determine absolute effects of $\mathrm{GH}$ administration on variables in the units of each variable. Heterogeneity between studies was assessed using a $Q$ parameter as defined by Cochran [66]. Given that ES may be skewed due to the results of a single study, we performed sensitivity analysis by excluding the study with the largest sample population per outcome measured.

To determine the effects of GH dose, subject gender, $\mathrm{GH}$ treatment duration, and subject age, studies were 
grouped based on the following and meta-analysis within each group performed: $G H$ dose-studies utilizing $<0.35$ $\mathrm{U} / \mathrm{kg} /$ week (low dose) and $\geq 0.35 \mathrm{U} / \mathrm{kg} /$ week of $\mathrm{GH}$ (high dose); subject gender - studies involving $<50 \%$ female or $\geq 50 \%$ female; $G H$ treatment duration - studies with GH treatment for $<6$ months, or $\geq 6$ months; subject agestudies involving patients $<40$ years old or $\geq 40$ years old. To compare the effects of $\mathrm{GH}$ and $\mathrm{T}$ administration, meta-analysis of the 2 included studies was performed. All analyses were conducted using the Statistical Package for Social Sciences (SPSS) (SPSS Inc., Chicago, IL) for Windows and Apple Macintosh, and Microsoft Excel (Microsoft, Inc., Redmond, WA).

\section{Results}

A meta-analysis of 48 studies involving 2231 patients with GHD was performed to assess the effects of GH on anthropomorphic, CV, and carbohydrate metabolism parameters (Table 1). Results are presented in terms of effect size (ES) calculated using a random-effects model after a $Q$ parameter calculation demonstrated minimal heterogeneity across studies, as well as in terms of the weighted mean difference (WMD) for each variable. Ninety-nine patients were lost or withdrew across all studies (Table 1). Causes of GHD were: $73 \%$ pituitary tumor, $11 \%$ idiopathic causes, and $16 \%$ other causes.

Table 1. Characteristics of studies included in the meta-analysis.

\begin{tabular}{|c|c|c|c|c|c|c|c|c|}
\hline First Author & Year & $\begin{array}{l}\text { Reference } \\
\text { Number }\end{array}$ & $\begin{array}{l}\text { Duration } \\
\text { (Months) }\end{array}$ & $\%$ Female & $\begin{array}{l}\text { Age (SD) } \\
\text { (Years) }\end{array}$ & $\begin{array}{c}\text { Total } \\
\text { Subjects }\end{array}$ & Variables Evaluated & $\begin{array}{l}\text { Subjects } \\
\text { Lost }\end{array}$ \\
\hline Cuneo, R.C. & 1991 & 17 & 6 & 33 & 38.5 (ND) & 24 & FS, LVM, SV & \\
\hline Cuneo, R.C. & 1993 & 19 & 6 & 33 & $38.0(9.8)$ & 24 & ApoB, HDL, LDL, Tchol, TG & \\
\hline Beshyah, S.A. & 1994 & 21 & 6 & 53 & 43.0 (ND) & 36 & DBP, EAR, EF, LVM, SBP & \\
\hline Russell-Jones, D.L. & 1994 & 22 & 2 & 56 & $46.6(9.1)$ & 18 & ApoB, HDL, LDL, Tchol, TG & \\
\hline Valcavi, R. & 1995 & 25 & 12 & 30 & $47.2(2.6)$ & 20 & EAR, EF, FS, HR, IGF1, LVM, SV & \\
\hline Nass, R. & 1995 & 24 & 6 & 25 & 44.7 (ND) & 20 & FS, IGF1, LBM, LVM & \\
\hline Beshyah, S.A. & 1995 & 23 & 6 & 53 & 44.0 (ND) & 40 & $\begin{array}{l}\text { ApoB, Fasting Glucose, Fasting } \\
\text { Insulin, HDL, LDL, Tchol, TG }\end{array}$ & \\
\hline Böger, R.H. & 1996 & 24 & 12 & 53 & $41.5(2.8)$ & 30 & HDL, LDL, Tchol, TG & 0 \\
\hline Webster, J.M. & 1997 & 31 & 6 & 33 & $44.3(10.0)$ & 18 & $\begin{array}{l}\text { BMI, Fasting Glucose, Fasting } \\
\text { Insulin, HgbA1c, Tchol }\end{array}$ & 0 \\
\hline Nolte, W. & 1997 & 30 & 12 & 47 & $41.6(10.7)$ & 32 & HDL, IGF1, LDL, Tchol, TG & 6 \\
\hline Hwu, C.M. & 1997 & 29 & 6 & 63 & $29.5(7.4)$ & 16 & $\begin{array}{l}\text { BMI, Fasting Glucose, FM, HDL, } \\
\text { IGF1, LDL, Tchol, TG, WHR }\end{array}$ & 5 \\
\hline Christ, E.R. & 1997 & 28 & 3 & 54 & $51.9(16.2)$ & 13 & $\begin{array}{l}\text { FM, IGF1SDS, IGFBP3SDS, } \\
\text { LBM, TBW }\end{array}$ & 0 \\
\hline Chipman, J.J. & 1997 & 27 & 6 & 33 & 37.4 (ND) & 165 & $\begin{array}{l}\text { Fasting Glucose, Fasting Insulin, } \\
\text { HgbA1C }\end{array}$ & 0 \\
\hline Cuneo, R.C. & 1998 & 32 & 6 & 44 & $40.5(1.5)$ & 163 & $\begin{array}{l}\text { DBP, Fasting Glucose, FFM, HDL, } \\
\text { IGF1SDS, IGFBP3, IGFBP3SDS, } \\
\text { LDL, SBP, TBW, Tchol, TG }\end{array}$ & 3 \\
\hline Leese, G.P. & 1998 & 33 & 6 & 67 & $35.0(12.1)$ & 30 & HDL, LDL, Tchol, TG & 2 \\
\hline Russell-Jones, D.L. & 1998 & 34 & 2 & 67 & $46.8(2.6)$ & 12 & $\begin{array}{l}\text { BMI, Fasting Glucose, Fasting } \\
\text { Insulin, IGF1, LBM }\end{array}$ & 0 \\
\hline Vahl, N. & 1998 & 35 & 12 & 37 & $44.5(1.8)$ & 27 & HDL, LDL, Tchol, TG & 0 \\
\hline Bell, W. & 1999 & 36 & 6 & 47 & $44.1(7.4)$ & 43 & FFM, TBW & 8 \\
\hline Christ, E.R. & 1999 & 38 & 3 & 61 & $48.9(5.3)$ & 18 & HDL, LDL, Tchol, TG & 3 \\
\hline Rosenfalck, A.M. & 1999 & 39 & 4 & 25 & $38.0(10.6)$ & 24 & $\begin{array}{l}\text { Fasting Glucose, Fasting Insulin, } \\
\text { FM, LBM, TRF }\end{array}$ & 0 \\
\hline Sönksen, P.H. & 1999 & 48 & 3 & 57 & $49.5(5.7)$ & 14 & $\begin{array}{l}\text { Fasting Insulin, HDL, HgbA1c, } \\
\text { IGF1SDS, IGFBP3SDS, LDL, Tchol, TG }\end{array}$ & 0 \\
\hline Fernholm, R. & 2000 & 40 & 6 & 19 & 68.5 (ND) & 31 & Fasting Insulin, FM, IGFBP3, LBM & 0 \\
\hline
\end{tabular}




\section{Continued}

\begin{tabular}{|c|c|c|c|c|c|c|c|c|}
\hline Sesmilo, G. & 2000 & 41 & 18 & 0 & $49.2(9.7)$ & 40 & $\begin{array}{l}\text { CRP, Fasting Glucose, Fasting } \\
\text { Insulin, LDL, Tchol, TG }\end{array}$ & 0 \\
\hline Ezzat, S. & 2002 & 42 & 6 & 42 & $46.5(12.1)$ & 115 & $\begin{array}{l}\text { EF, FM, IGF1, IGFBP3, LBM, } \\
\text { TBW, WHR }\end{array}$ & 0 \\
\hline Smith, J.C. & 2002 & 43 & 6 & 41 & $43.0(12.5)$ & 64 & DBP, HR, SBP & 0 \\
\hline Sneppen, S.B. & 2002 & 44 & 18 & 50 & 39.0 (ND) & 20 & EAR, FS & 2 \\
\hline Bramnert, M. & 2003 & 45 & 6 & 37 & $42.0(2.6)$ & 19 & $\begin{array}{l}\text { BMI, Fasting Glucose, Fasting } \\
\text { Insulin, IGF1, IGF1SDS, TBW }\end{array}$ & 0 \\
\hline Chihara, K. & 2004 & 47 & 6 & 52 & $38.0(8.4)$ & 64 & $\begin{array}{l}\text { IGF1, IGF!SDS, IGFBP3SDS, } \\
\text { LBM, LDL, Tchol }\end{array}$ & 0 \\
\hline Bell, W. & 2004 & 46 & 6 & 47 & $44.1(7.3)$ & 43 & $\begin{array}{l}\text { BMI, DBP, HDL, LDL, SBP, } \\
\text { Tchol, TG, TRG, WHR }\end{array}$ & 0 \\
\hline Christ, E.R. & 2004 & 37 & 3 & 54 & 49.5 (ND) & 13 & FM, HDL, HgbA1c, LBM, LDL, Tchol & 0 \\
\hline Hoffman, A.R. & 2004 & 50 & 12 & 48 & $48.2(\mathrm{ND})$ & 166 & Fasting Glucose, LBM, HgbA1c & 35 \\
\hline Elgzyri, T. & 2004 & 49 & 6 & 19 & $68.0(\mathrm{ND})$ & 31 & EAR, FS, HR & 3 \\
\hline Dutta, P. & 2010 & 57 & 3 & 0 & $47(3.9)$ & 26 & $\begin{array}{l}\text { BMI, FM, IGF1, LDL, HDL, TG, } \\
\text { Tchol, Fasting Glucose }\end{array}$ & 0 \\
\hline Chihara, K. & 2006 & 52 & 6 & 37 & $37.2(13.0)$ & 73 & $\begin{array}{l}\text { FM, HDL, IGF1, IGF1SDS, IGFBP3, } \\
\text { IGFBP3SDS, LBM, LDL, Tchol }\end{array}$ & 5 \\
\hline Bollerslev, J. & 2006 & 51 & 9 & 44 & 49.0 (ND) & 55 & CRP, HDL, LDL, Tchol, TG & 7 \\
\hline Chihara, K. & 2008 & 54 & 6 & 42 & $37.2(\mathrm{ND})$ & 116 & $\begin{array}{l}\text { FM, HDL, IGF1SDS, IGFBP3SDS, } \\
\text { LBM, LDL, Tchol, TG, TRF }\end{array}$ & 0 \\
\hline Beauregard, C. & 2008 & 53 & 6 & 100 & $46.2(\mathrm{ND})$ & 43 & $\begin{array}{l}\text { CRP, Fasting Glucose, Fasting Insulin, } \\
\text { FFM, FM, HDL, IGF1, IGF1SDS, } \\
\text { LDL, Tchol, TG, WHR }\end{array}$ & 0 \\
\hline Cittadini, A. & 2009 & 55 & 6 & 16 & $62.0(2.5)$ & 56 & $\begin{array}{l}\text { DBP, EF, Fasting Glucose, HR, } \\
\text { IGF1, LVM, SBP, Tchol, TG }\end{array}$ & 0 \\
\hline Miller, K. K. & 2010 & 58 & 6 & 50 & $46.8(12.3)$ & 30 & $\begin{array}{l}\text { CRP, Fasting Glucose, Fasting Insulin, } \\
\text { FFM, FM, HDL, HgbA1c, IGF1SDS, } \\
\text { LDL, Tchol, TG }\end{array}$ & 0 \\
\hline Whitehead, H.M. & 1992 & 18 & 6 & 36 & $29.4(2.7)$ & 10 & Fasting Glucose, FM, LBM, Tchol & 4 \\
\hline Chihara, K. & 2010 & 56 & 6 & 51 & $33.5(12.0)$ & 94 & IGFBP3SDS, LDL, Tchol & 0 \\
\hline Newman, C.B. & 2010 & 59 & 6 & 45 & $46.6(0)$ & 30 & $\begin{array}{l}\text { EAR, EF, FM, FS, HDL, LBM, } \\
\text { LDL, LVM, Tchol, TG, SV }\end{array}$ & 0 \\
\hline Russell-Jones, D.L. & 1993 & 20 & 2 & 55 & $46.6(2.2)$ & 18 & Fasting Insulin, IGF1, LBM & 0 \\
\hline Florkowski, C.M. & 1996 & 60 & 3 & 0 & 47.0 (ND) & 20 & BMI, WHR & 0 \\
\hline Beshyah, S.A. & 1995 & 61 & 6 & 53 & 44.0 (ND) & 40 & LBM, WHR & 0 \\
\hline Johannsson, G. & 1996 & 62 & 6 & 35 & $44.3(1.2)$ & 68 & BMI, FM, IGF1, TBW & 3 \\
\hline Snel, Y.E. & 1995 & 63 & 6 & 44 & ND & 25 & BMI, FFM, FM & 13 \\
\hline Mesa, J. & 2003 & 64 & 6 & 36 & $36.6(11.5)$ & 165 & $\begin{array}{l}\text { BMI, FFM, FM, IGF1, } \\
\text { IGFBP3, TBW, WHR }\end{array}$ & \\
\hline Sattler, F.R. & 2009 & 13 & 4 & 0 & $70.3(4.2)$ & 37 & FM, LBM & \\
\hline Blackman, M.R. & 2002 & 14 & 6 & 44 & $71.0(1.2)$ & 131 & FM, LBM & \\
\hline
\end{tabular}

IGF1: insulin-like growth factor 1; IGFBP3: insulin-like growth factor binding protein 3; WHR: waist-to-hip ratio; LBM: lean body mass; FFM: fat free mass; TrF: trunk fat; TBW: total body water; FM: fat mass; BMI: body mass index; SBP: systolic blood pressure; DBP: diastolic blood pressure; HR: heart rate; SV: stroke volume; LDL: low density lipoprotein; HDL: high density lipoprotein; TChol: total cholesterol; TG: triglycerides; ApoB: apolipoprotein B; CRP: C-reactive protein; EAR: E/A ratio; FS: fractional shortening; LVM: left ventricular mass; HgbA1c: hemoglobin A1c; SD: standard deviation. 


\subsection{Growth Hormone Serum Parameters}

Data for serum parameters evaluating GH administration were obtained from 19 studies involving 983 patients. Significant positive effects on IGF-1, a surrogate marker for GH used primarily due to its significantly longer half-life, and IGFBP3, a major IGF binding protein that is used to assess GH production in concert with IGF-1, were observed (Table 2, Figure 2). Due to lack of standardization of IGF-1 levels to age across all studies, a comprehensive z-score analysis that accounts for the effects of $\mathrm{GH}$ as a function of age could not be performed. The above data are in line with other studies demonstrating an increase in serum IGF-1 and IGFBP3 as a result of $\mathrm{GH}$ administration [40,42,52].

\subsection{Anthropomorphic Parameters}

Growth hormone enhances lean body mass through skele- tal muscle growth stimulation and fat loss [24,28,39]. We extracted data for waist-hip ratio (WHR), lean body mass (LBM)/fat free mass (FFM), trunk fat (TrF), total body water (TBW), fat mass (FM), and body mass index (BMI) from 28 studies involving 1464 patients (Table 2, Figure 2). Significant negative effects of $\mathrm{GH}$ administration were observed for WHR and FM, and significant positive effects observed for LBM, FFM, and TBW. No significant effects of GH administration were observed on $\operatorname{TrF}$ and BMI. Sensitivity analysis, in which the study with the largest patient population for each variable was removed from the analysis, demonstrated no significant changes in ES for all variables (Supplementary Table 1).

\subsection{Cardiovascular Parameters}

Given that GHD is associated with depressed systolic heart function and increased CV mortality, understanding

Table 2. Summary analysis of all variables.

\begin{tabular}{|c|c|c|c|c|c|c|c|c|c|}
\hline Variable & \# Studies & $\begin{array}{c}\text { Total } \\
\text { Subjects }\end{array}$ & $\begin{array}{c}\text { \# Drug } \\
\text { Subjects }\end{array}$ & $\begin{array}{c}\text { \# Placebo } \\
\text { Subjects }\end{array}$ & WMD (SD) & $\mathbf{Q}$ & ES & $\begin{array}{c}\text { ES } \\
\text { P-Value }\end{array}$ & ES 95\% CI \\
\hline IGF1 & 19 & 983 & 496 & 487 & $81.62(1.84) \mathrm{ng} / \mathrm{mL}$ & 0.00 & 6.90 & $<0.0001$ & $5.58,8.21$ \\
\hline IGFBP3 & 5 & 529 & 268 & 261 & $0.55(0.09) \mathrm{ng} / \mathrm{mL}$ & 0.00 & 2.36 & 0.0002 & $1.11,3.61$ \\
\hline WHR & 8 & 587 & 296 & 291 & $-0.03(0.08)$ & 0.00 & -2.79 & 0.0002 & $-4.25,-1.32$ \\
\hline LBM & 15 & 755 & 384 & 371 & $1.17(0.08) \mathrm{kg}$ & 0.00 & 1.15 & 0.0002 & $0.55,1.74$ \\
\hline FFM & 6 & 451 & 225 & 226 & $0.95(0.10) \mathrm{kg}$ & 0.00 & 1.04 & $<0.0001$ & $0.62,1.46$ \\
\hline $\operatorname{TrF}$ & 3 & 183 & 93 & 90 & $-1.80(0.18) \mathrm{kg}$ & 0.00 & -3.67 & 0.1256 & $-8.37,1.04$ \\
\hline TBW & 7 & 568 & 287 & 281 & $0.92(0.09) \mathrm{L}$ & 0.00 & 2.04 & 0.0001 & $1.00,3.08$ \\
\hline FM & 17 & 872 & 445 & 427 & $-1.35(0.08) \mathrm{kg}$ & 0.00 & -2.25 & $<0.0001$ & $-3.15,-1.35$ \\
\hline BMI & 10 & 412 & 211 & 201 & $-0.05(0.10) \mathrm{kg} / \mathrm{m}^{2}$ & 0.89 & -0.38 & $<0.0001$ & $-0.44,-0.32$ \\
\hline SBP & 5 & 344 & 169 & 175 & $-1.77(0.13) \mathrm{mmHg}$ & 0.00 & -0.98 & 0.3268 & $-2.94,0.98$ \\
\hline DBP & 5 & 344 & 169 & 175 & $-1.60(0.12) \mathrm{mmHg}$ & 0.00 & -0.68 & 0.4389 & $-2.40,1.04$ \\
\hline HR & 5 & 207 & 102 & 105 & $0.61(0.14)$ BPM & 0.00 & 0.70 & 0.1327 & $-0.21,1.61$ \\
\hline SV & 3 & 104 & 51 & 53 & $-0.49(0.24) \mathrm{mL}$ & 0.05 & 0.28 & 0.5092 & $-0.55,1.10$ \\
\hline LDL & 23 & 1045 & 524 & 521 & $-8.07(0.20) \mathrm{mg} / \mathrm{dL}$ & 0.00 & -1.09 & $<0.0001$ & $-1.49,-0.70$ \\
\hline HDL & 21 & 918 & 460 & 458 & $0.97(0.07) \mathrm{mg} / \mathrm{dL}$ & 0.00 & 0.37 & 0.032 & $0.03,0.71$ \\
\hline TChol & 26 & 1139 & 572 & 567 & $-7.09(0.16) \mathrm{mg} / \mathrm{dL}$ & 0.00 & -0.83 & $<0.0001$ & $-1.12,-0.54$ \\
\hline TG & 21 & 961 & 481 & 480 & $-1.22(0.07) \mathrm{mg} / \mathrm{dL}$ & 0.00 & -0.14 & 0.4225 & $-0.49,0.2$ \\
\hline ApoB & 3 & 82 & 41 & 41 & $-0.12(0.22) \mathrm{g} / \mathrm{L}$ & 0.52 & -0.76 & $<0.0001$ & $-1.09,-0.44$ \\
\hline CRP & 4 & 223 & 110 & 113 & $-1.02(0.14) \mathrm{mg} / \mathrm{L}$ & 0.00 & -1.24 & 0.0284 & $-2.35,-0.13$ \\
\hline EAR & 5 & 137 & 66 & 71 & $0.02(0.17)$ & 0.75 & 0.23 & $<0.0001$ & $0.13,0.34$ \\
\hline FS & 6 & 145 & 71 & 74 & $0.68(0.17) \%$ & 0.00 & 0.44 & 0.4036 & $-0.59,1.47$ \\
\hline LVM & 6 & 186 & 91 & 95 & $-0.96(0.16) \mathrm{g}$ & 0.00 & 0.05 & 0.8633 & $-0.52,0.62$ \\
\hline Fasting Insulin & 12 & 454 & 228 & 226 & $1.63(0.11) \mu \mathrm{IU} / \mathrm{mL}$ & 0.00 & 1.30 & 0.0001 & $0.69,1.91$ \\
\hline Fasting Glucose & 15 & 480 & 242 & 238 & $1.60(0.08) \mathrm{mg} / \mathrm{dL}$ & 0.00 & 0.64 & 0.0144 & $0.13,1.16$ \\
\hline HgbA1c & 7 & 446 & 227 & 219 & $0.05(0.10) \%$ & 0.01 & 0.48 & 0.0155 & $0.09,0.87$ \\
\hline
\end{tabular}

\#Studies: number of studies in which a given variable was assessed; WMD: weighted mean difference; SD: standard deviation; Q: Q parameter; ES: effect size; CI: $-95 \%$ confidence interval. 


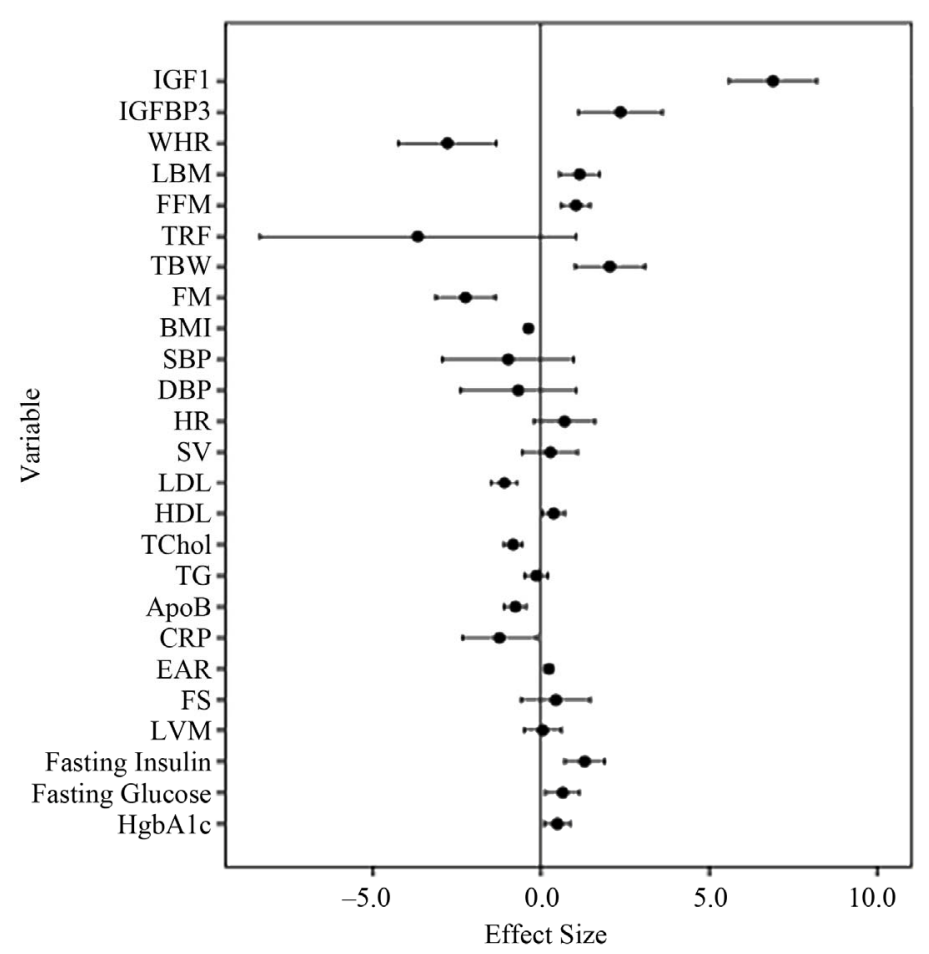

IGF1: insulin-like growth factor 1; IGFBP3: insulin-like growth factor binding protein 3; WHR: waist-to-hip ratio; LBM: lean body mass; FFM: fat free mass; TrF: trunk fat; TBW: total body water; FM: fat mass; BMI: body mass index; SBP: systolic blood pressure; DBP: diastolic blood pressure; HR: heart rate; SV: stroke volume; LDL: low density lipoprotein; HDL: high density lipoprotein; TChol: total cholesterol; TG: triglycerides; ApoB: apolipoprotein B; CRP: C-reactive protein; EAR: E/A ratio; FS: fractional shortening; LVM: left ventricular mass; HgbAlc: hemoglobin A1c.

Figure 2. Forest plot of effect sizes for all variables assessed.

whether $\mathrm{GH}$ replacement improves heart function and decreases mortality risk is essential $[67,68]$. We extracted data assessing systolic and diastolic blood pressure (SBP, DBP), heart rate (HR), stroke volume (SV), LDL, HDL, total cholesterol (TChol), total triglycerides (TG), apolipoprotein B (ApoB), C-reactive protein (CRP), the early to late ventricular diastolic filling (E/A) ratio (EAR), left ventricular mass (LVM) and left ventricular fractional shortening (FS) from 33 studies involving 1269 patients (Table 2, Figure 2). Significant negative effects of GH administration were observed on LDL, TChol, ApoB, and CRP, and a small but significant positive effect was seen on EAR and HDL cholesterol. No effect was observed for SBP, DBP, HR, SV, TG, LVM, or FS.

Sensitivity analysis demonstrated significant positive effects for SV and HR, and no significant change in EAR and CRP, indicating that the contributions of individual studies were significant in the determination of our initial results (Supplementary Table 1). While our results with regards to the effects of GH on LDL and TChol are in line with those of a prior meta-analysis, we find no significant decrease in DBP in our study, in contrast with prior findings [9]. In addition, while a prior meta-analysis had identified an increase in $\mathrm{SV}$ as a function of $\mathrm{GH}$ administration, we find no significant effect on SV in our analysis, except when excluding the largest study analyzing SV, which evaluated 30 patients of a total of 104 evaluated for SV in our analysis (Supplementary Table 1) $[10,59]$.

\subsection{Carbohydrate Metabolism}

$\mathrm{GH}$ is known to impair glucose tolerance and antagonize insulin action through an incompletely defined mechanism [69]. Data from 19 studies involving 913 patients were analyzed, demonstrating that GH produces a significant increase in fasting insulin, glucose and HgbA1c (Table 2, Figure 2). These data are largely in agreement with those of prior studies. However, while our analysis demonstrates a significant increase in $\mathrm{HgbA1c}$, numerous included studies found no change in HgbA1c levels $[41,52]$. A sensitivity analysis demonstrated no change in significance of ESs across assayed variables (Supplementary Table 1) [23,28,33].

\subsection{Sex Steroids}

Evaluation for hypogonadism and subsequent $\mathrm{T}$ replacement is commonplace in the aging male population, 
whereas testing for GHD is far less common. In addition, in individuals using anabolic steroids, it is of interest to assess whether the use of GH can offset potentially deleterious CV effects associated with steroid use, including increased LDL, decreased HDL, elevated SBP and DBP, and changes in cardiac electrophysiology and left ventricular size [70]. However, few controlled studies exist assessing the role of $\mathrm{GH}$ administration in the setting of $\mathrm{T}$ replacement. We identified 2 randomized, placebocontrolled studies involving 184 patients comparing $\mathrm{T}$ replacement to $\mathrm{GH}$ and $\mathrm{T}$ or $\mathrm{GH}$ replacement to placebo and performed a nested meta-analysis of FM and LBM, the only common variables assessed by these studies. We observed a significant negative effect of GH on FM and a significant positive effect on LBM in comparison to placebo, in agreement with our larger analysis above (Table 3). When comparing administration of $\mathrm{GH}$ and $\mathrm{T}$ simultaneously with administration of $\mathrm{T}$ alone, we observed a significant negative effect of GH and T on FM but not on LBM. Finally, when comparing simultaneous GH and T administration to $\mathrm{GH}$ alone, we observe no significant effect of the combination on FM or LBM. Taken together these data suggest that $\mathrm{GH}$ has a more pronounced effect on FM and LBM than T.

\subsection{Effect of GH Dose}

To better define the effects of GH dose, we meta-analyzed studies segregated based on a GH dose cutoff of $0.35 \mathrm{U} / \mathrm{kg} /$ week. We analyzed 37 studies involving 1788 patients that utilized a GH dose of $<0.35 \mathrm{U} / \mathrm{kg} /$ week (low dose), and 11 studies involving 443 patients that utilized a GH dose of $\geq 0.35 \mathrm{U} / \mathrm{kg} /$ week (high dose), and find that a high dose of GH results in a significantly greater effect on FS compared to low dose GH $(\mathrm{P}=0.012)$ (Supplementary Table 2).

\subsection{Effect of Gender}

In order to define the effects of gender, we performed meta-analysis using a cutoff of $50 \%$ of females in any given study. Using these criteria, we analyzed 30 studies involving 1713 patients with $<50 \%$ females and 18 studies involving 518 patients with $\geq 50 \%$ females, and find no significant differences between variables as a function of gender (Supplementary Table 3).

\subsection{Effect of Treatment Duration}

To compare the effects of $\mathrm{GH}$ as a function of treatment duration, we meta-analyzed studies using a cutoff of 6 months duration (Supplementary Table 4). We included 10 studies involving 176 patients of $<6$ months duration and 38 studies involving 2055 patients of $\geq 6$ months duration. We observe a significantly greater negative effect of $\mathrm{GH}$ administration on BMI $(\mathrm{P}=0.03)$ in patients treated for $\geq 6$ months.

\subsection{Effect of Age}

To compare the effects of $\mathrm{GH}$ as a function of subject age, we meta-analyzed studies using a cutoff of 40 years of age in order to have sufficient data for analysis in both groups. Using this criterion, we included 14 studies involving 819 patients $<40$ years old and 34 studies involving 1412 patients $\geq 40$ years old. We find no significant differences between variables as a function of age (Supplementary Table 5).

\section{Discussion}

Growth hormone has been used for treatment of GHD since 1958, when it was first purified from human pituitary glands. In the $1980 \mathrm{~s}$, recombinant GH became available and permitted widespread treatment of GHD, prompting study of the GHD population [8]. Since the most recent meta-analysis that evaluated $\mathrm{CV}$, carbohydrate, and lipid parameters, numerous randomized, controlled studies evaluating the effects of $\mathrm{GH}$ have been published. Our goal was to update the literature with regards to the $\mathrm{GH}$ effect in the above parameters through meta-analysis of randomized, controlled trials.

Table 3. Nested meta-analysis of studies assessing concomitant sex steroid and GH administration.

\begin{tabular}{cccccc}
\hline GH + Testosterone vs. Placebo & & & & & \\
\hline Variable & \# Studies & \# Subjects & ES & P-Value & WMD (SD) \\
FM & 2 & 184 & -2.81 & $<0.0001$ & $-2.46(0.35) \mathrm{kg}$ \\
LBM & 2 & 184 & 2.21 & 0.0417 & $2.11(0.33) \mathrm{kg}$ \\
GH + Testosterone vs. Testosterone & & & & & \\
FM & 2 & 184 & -1.83 & $<0.0001$ & $-1.96(0.32) \mathrm{kg}$ \\
LBM & 2 & 184 & 1.91 & 0.1223 & $1.58(0.30) \mathrm{kg}$ \\
GH + Testosterone vs. GH & & & & & \\
FM & 2 & 184 & -0.55 & 0.2915 & $-1.10(0.28) \mathrm{kg}$ \\
LBM & 2 & 184 & 0.55 & 0.3859 & $0.89(0.28) \mathrm{kg}$ \\
\hline
\end{tabular}

ES: effect size; WMD: weighted mean difference; SD: standard deviation. 


\subsection{Growth Hormone Serum Effects}

In most included studies baseline IGF-1 and IGFBP3 levels were $<100 \mathrm{ng} / \mathrm{mL}$, with a significant increase in serum IGF-1 levels of $\sim 81 \mathrm{ng} / \mathrm{mL}$ after GH administration (Table 2). This is in line with prior data, which demonstrate a 1-3 fold increase in IGF-1 levels after 6 12 months of GH therapy [24,25,30,32,33]. GH therapy is also associated with increased serum insulin binding protein levels, specifically IGFBP3, which is in line with our findings [71,72]. However, the effects of $\mathrm{GH}$ on levels of other IGFBPs are not well established and of studies that have evaluated the relationship between GH and these other IGFBPs, no correlation has been observed $[42,73]$.

\subsection{Anthropomorphic and CV Effects}

GHD in adults is associated with increased vascular mortality rates $[19,22]$. Previous studies have attributed this trend to adverse effects on anthropomorphic and CV parameters such as increased total cholesterol, LDL, WHR, and adiposity and decreased HDL $[3,7,19,32]$. In our analysis, we observed improvement in several of these parameters after $\mathrm{GH}$ administration, with increases in both LBM and FFM, and a decrease in the WHR. No significant change in body weight was found regardless of the modality used to assess these variables. Decreases in LDL, TChol, ApoB, and CRP, and an increase in HDL were also observed. Most studies that assessed these variables were 6 months long, with several of 12 months duration (Table 1) [12,18,41,46,48,52-54,58,59,67]. Approximately half of the included studies find an increase in HDL (3 of 8) and/or decrease in LDL (5 of 9), whereas the majority of studies find a decrease in TChol (7 of 9), and no studies find a change in TG (7 of 7). Two studies found the decrease in LDL and total cholesterol to be transient, limited to the first 3 - 12 months of therapy [31, 41]. We observe significant ESs for LDL, HDL, and TChol in our analysis, which coincides with the results of the most recent meta-analysis to evaluate serum lipids in the setting of GH administration, though in that study the change in HDL was not statistically significant [9]. Mechanistically, GH increases hepatic uptake of very low density lipoprotein (VLDL) cholesterol and this may decrease conversion of VLDL to LDL, potentially explaining the above effect [74]. The effect of GH treatment duration on serum lipids is a debated topic. We observed no significant differences in LDL, TChol, or HDL when assessing the effects of GH treatment duration. However this may be due to the lack of studies of longer than 12 months duration.

We find no change in SBP, DBP, HR, SV, LVM, or FS, and a small, but significant positive effect on the EAR resulting from increases in EAR in 2 studies $[21,25]$.
These findings echo those of a prior meta-analysis for SBP, though a significant decrease in DBP was demonstrated in that study, which is not recapitulated in our study [9]. Other non-placebo controlled studies not included in this analysis have shown a statistically significant moderate increase in systolic and diastolic blood pressure secondary to GH treatment $[75,76]$. These differences in effect on BP may be secondary to mechanism of measurement, specifically ambulatory monitoring vs. conventional sphygmomanometer. A recent controlled trial of GH administration using $0.26 \mathrm{U} / \mathrm{kg} / \mathrm{wk}$ of $\mathrm{GH}$ demonstrated no changes in EAR, SV, or FS [59]. In contrast, an earlier study used $0.35 \mathrm{U} / \mathrm{kg} / \mathrm{wk}$ of $\mathrm{GH}$ and demonstrated increases in EAR, SV, and FS [25]. Studies utilizing GH doses of $0.10-0.20 \mathrm{U} / \mathrm{kg} /$ week demonstrated no changes in EAR or FS, supporting previous conclusions that the $\mathrm{CV}$ effects of $\mathrm{GH}$ are likely related to dose $[44,49]$, which is also supported by the finding that acromegaly results in increased CV mortality [77]. Earlier studies using higher GH doses demonstrated increases in LVM and other echocardiographic indices of heart function [25,78], whereas more recent studies using lower GH doses demonstrate no changes in these indices, suggesting that lower dose $\mathrm{GH}$ regimens are safer for cardiac function $[18,24,25,79]$. These data suggest that $\mathrm{GH}$ administration in low to moderate doses results in normalization of cardiac performance and may have cardioprotective effects in patients with GHD, who have a 1.9-fold increased risk of CV mortality [68]. Notably, GH has been shown to normalize nitric oxide production when administered to GHD individuals, suggesting a molecular mechanism for enhanced cardiac performance, as well as cardioprotection [26]. However a recent uncontrolled 12-month trial of GH treatment concluded that GH increases carotid intima media thickness (IMT), ultimately leading to an increased number of atherosclerotic plaques [80]. In our analysis, only one study included IMT as an endpoint, in which the result was not significant. Longer duration studies are necessary to determine whether these changes have an overall effect on CV mortality.

\subsection{Carbohydrate Metabolism}

GH therapy has been implicated in development of insulin resistance and type II diabetes [69]. Our data show that $\mathrm{GH}$ produces a significant increase in fasting insulin and fasting glucose, which is likely related to GH's insulin antagonizing effect $[29,69]$. The incidence of diabetes among the studies we analyzed was variable, though no studies reported new diagnoses of diabetes as a result of $\mathrm{GH}$ administration despite reporting increases in fasting insulin and glucose levels that potentially signify insulin resistance. Notably, few studies discussed diabetes in the 
context of increased insulin and glucose levels, making it difficult to assess whether diabetes was affected by GH treatment.

Insulin resistance due to $\mathrm{GH}$ may be a transient effect that subsides within $3-6$ months of the onset of GH therapy, as normalization of insulin-mediated glucose disposal in the setting of persistently elevated fasting insulin and C-peptide levels after 3 months of GH treatment has been observed [81]. These results have been reproduced by others $[23,82]$, and reports supporting the conclusion that GHD induces a state of insulin resistance that is then normalized by $\mathrm{GH}$ administration are also available [29, 83]. A recent study conducted over 4 years concluded that there was no evidence of increased DM incidence in GHD patients on GH treatment [84]. However, more recent studies have demonstrated a persistent state of insulin resistance through 6 months of GH treatment that is linked to a switch from glucose clearance to lipid oxidation [45]. In addition, we find a small, significant increased effect on $\mathrm{HgbA1c}$, which further supports a role for persistent dysregulation of glucose metabolism by $\mathrm{GH}$. Given that most studies of GH administration do not go past 18 months, the long-term effects of GH administration on glucose metabolism bear additional study, particularly in the setting of a 6-fold increase in type 2 diabetes in children treated with GH [69].

\subsection{Safety}

The long-term safety of GH administration remains unclear, as most studies evaluate the safety profiles of $\mathrm{GH}$ administration over only 6 - 18 months. Lower dose GH therapy appears to be safer in the short term from the CV perspective, as described above, although the long-term $\mathrm{CV}$ and stroke risk in GH-treated patients remains unknown. A recent observational study in 281 patients with ischemic stroke demonstrated a minimal contribution of $\mathrm{GH}$ to the risk of poor functional outcome and death in these patients [85]. However, a study in female rats demonstrated that low IGF-1 levels increased the contribution of estrogen to ischemic stroke risk, suggesting that GHD may contribute to stroke risk in humans [86]. In addition, no controlled studies exist examining the use of GH with anabolic steroids in individuals without GHD, and thus the safety and efficacy of GH use in this population remains unclear [87]. Our study was unable to effectively assess adverse effects of GH treatment, as only 5 of the 48 studies utilized included such data.

\subsection{Study Limitations}

While this meta-analysis attempted to account for possible variations in effect size through an assessment of treatment duration, GH treatment dose, gender, and age, one important factor that is missing is the onset of GHD.
Previous studies have observed differences in IGF-1 level and response between childhood and adult onset GHD subjects, specifically that childhood onset GHD adults have a lower baseline IGF-1 level and a greater improvement in quality of life $[88,89]$. However in our analysis, only 3 studies included information on timing of GHD onset $[27,47,56]$; this subject was therefore not included in the subgroup analysis.

\subsection{Future Directions}

Our data argue that GH treatment in the setting of GHD results in positive changes in anthropomorphic indices, as well as beneficial changes in CV parameters. However the long-term risk of stroke and myocardial infarction rates related to $\mathrm{GH}$ administration are unknown and will need to be determined in future studies. While GH therapy appears to negatively affect insulin and glucose metabolism, whether this results in development of diabetes mellitus remains an unanswered question. Furthermore, no safety or efficacy data are available for GH administration in the non-GHD population, and very limited data exist on the interaction between $\mathrm{GH}$ and testosterone. Finally, while the risk of malignancy resulting from $\mathrm{GH}$ administration appears low, the true long-term effects of GH therapy on malignancy need to be further elucidated, and multiple additional populations assessed. Further work should focus on these unanswered questions with regard to $\mathrm{GH}$ administration.

\subsection{Conclusion}

GH treatment in GHD adults results in beneficial effects on total cholesterol, LDL, HDL, ApoB, CRP, LBM, FFM and WHR. As expected, GH reduces insulin sensitivity with increases in fasting insulin, fasting glucose and HgbA1C. Data on long-term safety, including on CV effects, insulin sensitivity and malignancy, as well as data assessing the role of GH replacement in combination with testosterone replacement needs to be assessed in larger, long-term trials.

\section{REFERENCES}

[1] A. S. Bates, et al., "The Effect of Hypopituitarism on Life Expectancy," The Journal of Clinical Endocrinology \& Metabolism, Vol. 84, No. 3, 1996, pp. 1169-1172. doi:10.1210/jc.81.3.1169

[2] A. L. Barkan, et al., "Growth Hormone Therapy for Hypopituitary Adults: Time for Re-Appraisal," Trends in Endocrinology \& Metabolism, Vol. 11, No. 6, 2000, pp. 238-245. doi:10.1016/S1043-2760(00)00267-8

[3] R. C. Cuneo, et al., "The Growth Hormone Deficiency Syndrome in Adults," Clinical Endocrinology, Vol. 37, No. 5, 1992, pp. 387-397. doi:10.1111/j.1365-2265.1992.tb02347.x 
[4] P. B. Mark, et al., "Cardiomyopathy Induced by Performance Enhancing Drugs in a Competitive Bodybuilder," Heart, Vol. 91, No. 7, 2005, p. 888. doi:10.1136/hrt.2004.053843

[5] Q. E. Stevens, et al., "Aortic and Mitral Valve Thickening with Concentric Left Ventricular Hypertrophy in an Elite Bodybuilder: A Biochemical and/or Physiological Adaptation?" Cardiology, Vol. 98, No. 3, 2002, pp. 159-161. doi:10.1159/000066315

[6] M. J. Geraci, et al., "New Onset Diabetes Associated with Bovine Growth Hormone and Testosterone Abuse in a Young Body Builder," Human \& Experimental Toxicology, Vol. 30, No. 12, 2011, pp. 2007-2012.

[7] B. P. Brennan, et al., "Human Growth Hormone Abuse in Male Weightlifters," American Journal on Addictions, Vol. 20, No. 1, 2011, pp. 9-13. doi:10.1111/j.1521-0391.2010.00093.x

[8] P. V. Carroll, et al., "Growth Hormone Deficiency in Adulthood and the Effects of Growth Hormone Replacement: A Review," The Journal of Clinical Endocrinology \& Metabolism, Vol. 83, No. 2, 1998, pp. 382-395. doi:10.1210/jc.83.2.382

[9] P. Maison, et al., "Impact of Growth Hormone (GH) Treatment on Cardiovascular Risk Factors in GH-Deficient Adults: A Metaanalysis of Blinded, Randomized, Placebo-Controlled Trials," The Journal of Clinical Endocrinology \& Metabolism, Vol. 89, No. 5, 2004, pp. 2192-2199. doi:10.1210/jc.2003-030840

[10] P. Maison, et al., "Cardiac Effects of Growth Hormone in Adults with Growth Hormone Deficiency: A MetaAnalysis," Circulation, Vol. 108, No. 21, 2003, pp. 26482652. doi:10.1161/01.CIR.0000100720.01867.1D

[11] L. I. Arwert, et al., "The Influence of Growth Hormone (GH) Substitution on Patient-Reported Outcomes and Cognitive Functions in GH-Deficient Patients: A MetaAnalysis," Growth Hormone \& IGF Research, Vol. 15, No. 1, 2005, pp. 47-54. doi:10.1016/j.ghir.2004.11.004

[12] W. M. Widdowson, et al., "The Effect of Growth Hormone Replacement on Exercise Capacity in Patients with GH Deficiency: A Metaanalysis," The Journal of Clinical Endocrinology \& Metabolism, Vol. 93, No. 11, 2008, pp. 4413-4417. doi:10.1210/jc.2008-1239

[13] F. R. Sattler, et al., "Testosterone and Growth Hormone Improve Body Composition and Muscle Performance in Older Men," The Journal of Clinical Endocrinology \& Metabolism, Vol. 94, No. 6, 2009, pp. 1991-2001. doi:10.1210/jc.2008-2338

[14] M. R. Blackman, et al., "Growth Hormone and Sex Steroid Administration in Healthy Aged Women and Men: A Randomized Controlled Trial," The Journal of the American Medical Association, Vol. 288, No. 18, 2002, pp. 2282-2292. doi:10.1001/jama.288.18.2282

[15] P. H. Sonksen, et al., "Consensus Guidelines for the Diagnosis and Treatment of Adults with Growth Hormone Deficiency," Growth Hormone \& IGF Research, Vol. 8, 1998, pp. 89-92.

[16] "Consensus Guidelines for the Diagnosis and Treatment of Adults with Growth Hormone Deficiency: Summary Statement of the Growth Hormone Research Society
Workshop on Adult Growth Hormone Deficiency," The Journal of Clinical Endocrinology \& Metabolism, Vol. 83, No. 2, 1998, pp. 379-381. doi:10.1210/jc.83.2.379

[17] R. C. Cuneo, et al., "Cardiovascular Effects of Growth Hormone Treatment in Growth-Hormone-Deficient Adults: Stimulation of the Renin-Aldosterone System," Clinical Science, Vol. 81, No. 5, 1991, pp. 587-592.

[18] H. M. Whitehead, et al., "Growth Hormone Treatment of Adults with Growth Hormone Deficiency: Results of a 13-Month Placebo Controlled Cross-Over Study," Clinical Endocrinology, Vol. 36, No. 1, 1992, pp. 45-52. doi:10.1111/j.1365-2265.1992.tb02901.x

[19] R. C. Cuneo, et al., "Growth Hormone Treatment Improves Serum Lipids and Lipoproteins in Adults with Growth Hormone Deficiency," Metabolism, Vol. 42, No. 12, 1993, pp. 1519-1523. doi:10.1016/0026-0495(93)90145-E

[20] D. L. Russell-Jones, et al., "The Effects of Growth Hormone on Protein Metabolism in Adult Growth Hormone Deficient Patients," Clinical Endocrinology, Vol. 38, No. 4, 1993, pp. 427-431. doi:10.1111/j.1365-2265.1993.tb00525.x

[21] S. A. Beshyah, et al., "Cardiovascular Effects of Growth Hormone Replacement Therapy in Hypopituitary Adults," European Journal of Endocrinology, Vol. 130, No. 5, 1994, pp. 451-458. doi:10.1530/eje.0.1300451

[22] D. L. Russell-Jones, et al., "The Effect of Growth Hormone Replacement on Serum Lipids, Lipoproteins, Apolipoproteins and Cholesterol Precursors in Adult Growth Hormone Deficient Patients," Clinical Endocrinology, Vol. 41, No. 3, 1994, pp. 345-350. doi:10.1111/j.1365-2265.1994.tb02555.x

[23] S. A. Beshyah, et al., "The Effects of Short and LongTerm Growth Hormone Replacement Therapy in Hypopituitary Adults on Lipid Metabolism and Carbohydrate Tolerance," The Journal of Clinical Endocrinology \& Metabolism, Vol. 80, No. 2, 1995, pp. 356-363. doi:10.1210/jc.80.2.356

[24] R. Nass, et al., "Effect of Growth Hormone (hGH) Replacement Therapy on Physical Work Capacity and Cardiac and Pulmonary Function in Patients with hGH Deficiency Acquired in Adulthood," The Journal of Clinical Endocrinology \& Metabolism, Vol. 80, No. 2, 1995, pp. 552-557. doi: $10.1210 /$ jc.80.2.552

[25] R. Valcavi, et al., "Cardiac Performance and Mass in Adults with Hypopituitarism: Effects of One Year of Growth Hormone Treatment," The Journal of Clinical Endocrinology \& Metabolism, Vol. 80, No. 2, 1995, pp. 659-666. doi: $10.1210 /$ jc.80.2.659

[26] R. H. Boger, et al., "Nitric Oxide May Mediate the Hemodynamic Effects of Recombinant Growth Hormone in Patients with Acquired Growth Hormone Deficiency. A Double-Blind, Placebo-Controlled Study," Journal of Clinical Investigation, Vol. 98, No. 12, 1996, pp. 27062713. doi:10.1172/JCI119095

[27] J. J. Chipman, et al., "The Safety Profile of GH Replacement Therapy in Adults," Clinical Endocrinology, Vol. 46, No. 4, 1997, pp. 473-481. doi:10.1046/j.1365-2265.1997.1660984.x 
[28] E. R. Christ, et al., "The Importance of Growth Hormone in the Regulation of Erythropoiesis, Red Cell Mass, and Plasma Volume in Adults with Growth Hormone Deficiency," The Journal of Clinical Endocrinology \& Metabolism, Vol. 82, No. 9, 1997, pp. 2985-2990. doi:10.1210/jc.82.9.2985

[29] C. M. Hwu, et al., "Growth Hormone (GH) Replacement Reduces Total Body Fat and Normalizes Insulin Sensitivity in GH-Deficient Adults: A Report of One-Year Clinical Experience. The Journal of Clinical Endocrinology \& Metabolism, Vol. 82, No. 1, 1997, pp. 3285-3292. doi:10.1210/jc.82.10.3285

[30] W. Nolte, et al., "The Effect of Recombinant Human GH Replacement Therapy on Lipoprotein(a) and Other Lipid Parameters in Adults with Acquired GH Deficiency: Results of a Double-Blind and Placebo-Controlled Trial," European Journal of Endocrinology, Vol. 137, No. 5, 1997, pp. 459-466. doi:10.1530/eje.0.1370459

[31] J. M. Webster, et al., "The Effect of Growth Hormone Replacement Therapy for up to 12 Months on Lipoprotein Composition and Lipoprotein(a) in Growth Hormone-Deficient Adults," Atherosclerosis, Vol. 133, No. 1, 1997, pp. 115-121. doi:10.1016/S0021-9150(97)00110-X

[32] R. C. Cuneo, et al., "The Australian Multicenter Trial of Growth Hormone (GH) Treatment in GH-Deficient Adults," The Journal of Clinical Endocrinology \& Metabolism, Vol. 83, No. 1, 1998, pp. 107-116. doi:10.1210/jc.83.1.107

[33] G. P. Leese, et al., "HDL-Cholesterol Reductions Associated with Adult Growth Hormone Replacement," Clinical Endocrinology, Vol. 49, No. 5, 1998, pp. 673-677. doi:10.1046/j.1365-2265.1998.00597.x

[34] D. L. Russell-Jones, et al., "Effect of Growth Hormone Treatment on Postprandial Protein Metabolism in Growth Hormone-Deficient Adults," American Journal of Physiology, Vol. 274, 1998, pp. 1050-1056.

[35] N. Vahl, et al., "The Favourable Effects of Growth Hormone (GH) Substitution on Hypercholesterolaemia in GH-Deficient Adults Are Not Associated with Concomitant Reductions in Adiposity. A 12 Month Placebo-Controlled Study," International Journal of Obesity, Vol. 22, No. 6, 1998, pp. 529-536. doi:10.1038/sj.ijo.0800618

[36] W. Bell, et al., "Strength and Its Relationship to Changes in Fat-Free Mass, Total Body Potassium, Total Body Water and IGF-1 in Adults with Growth Hormone Deficiency: Effect of Treatment with Growth Hormone," Annals of Human Biology, Vol. 26, No. 1, 1999, pp. 63-78. doi:10.1080/030144699282985

[37] E. R. Christ, et al., "Effects of Growth Hormone (GH) Replacement Therapy on Very Low Density Lipoprotein Apolipoprotein B100 Kinetics in Patients with Adult GH Deficiency: A Stable Isotope Study," The Journal of Clinical Endocrinology \& Metabolism, Vol. 84, No. 1, 1999, pp. 307-316. doi:10.1210/jc.84.1.307

[38] E. R. Christ, et al., "Growth Hormone (GH) Replacement Therapy Reduces Serum Sialic Acid Concentrations in Adults with GH-Deficiency: A Double-Blind PlaceboControlled Study," Clinical Endocrinology, Vol. 51, No. 2, 1999, pp. 173-179. doi:10.1046/j.1365-2265.1999.00751.x
[39] A. M. Rosenfalck, et al., "The Effect of the Deterioration of Insulin Sensitivity on Beta-Cell Function in GrowthHormone-Deficient Adults Following 4-Month Growth Hormone Replacement Therapy," Growth Hormone \& IGF Research, Vol. 9, No. 2, 1999, pp. 96-105. doi:10.1054/ghir.1999.0091

[40] R. Fernholm, et al., "Growth Hormone Replacement Therapy Improves Body Composition and Increases Bone Metabolism in Elderly Patients with Pituitary Disease," The Journal of Clinical Endocrinology \& Metabolism, Vol. 85, No. 11, 2000, pp. 4104-4112. doi:10.1210/jc.85.11.4104

[41] G. Sesmilo, et al., "Effects of Growth Hormone Administration on Inflammatory and Other Cardiovascular Risk Markers in Men with Growth Hormone Deficiency. A Randomized, Controlled Clinical Trial," Annals of Internal Medicine, Vol. 133, No. 2, 2000, pp. 111-122.

[42] S. Ezzat, et al., "Gender-Specific Responses of Lean Body Composition and Non-Gender-Specific Cardiac Function Improvement after GH Replacement in GH-Deficient Adults," The Journal of Clinical Endocrinology \& Metabolism, Vol. 87, No. 6, 2002, pp. 2725-2733. doi:10.1210/jc.87.6.2725

[43] J. C. Smith, et al., "Effects of GH Replacement on Endothelial Function and Large-Artery Stiffness in GH-Deficient Adults: A Randomized, Double-Blind, PlaceboControlled Study," Clinical Endocrinology, Vol. 56, No. 4, 2002, pp. 493-501. doi:10.1046/j.1365-2265.2002.01514.x

[44] S. B. Sneppen, et al., "Cardiac Effects of Low-Dose Growth Hormone Replacement Therapy in Growth Hormone-Deficient Adults. An 18-Month Randomised, Placebo-Controlled, Double-Blind Study," Hormone Research, Vol. 58, No. 1, 2002, pp. 21-29.

[45] M. Bramnert, et al., "Growth Hormone Replacement Therapy Induces Insulin Resistance by Activating the Glucose-Fatty Acid Cycle," The Journal of Clinical Endocrinology \& Metabolism, Vol. 88, No. 4, 2003, pp. 1455-1463. doi:10.1210/jc.2002-020542

[46] W. Bell, et al., "Somatic Characteristics and Cardiovascular Risk Factors in Growth Hormone Deficiency: A Randomized, Double-Blind, Placebo-Controlled Study of the Effect of Treatment with Recombinant Human Growth Hormone," American Journal of Human Biology, Vol. 16, No. 5, 2004, pp. 533-543. doi:10.1002/ajhb.20055

[47] K. Chihara, et al., "Adult GH Deficiency in Japanese Patients: Effects of GH Treatment in a Randomised, Placebo-Controlled Trial," European Journal of Endocrinology, Vol. 151, No. 3, 2004, pp. 343-350. doi: $10.1530 /$ eje. 0.1510343

[48] E. R. Christ, et al., "Effects of Growth Hormone (GH) Replacement Therapy on Low-Density Lipoprotein Apolipoprotein B100 kinetics in Adult Patients with GH Deficiency: A Stable Isotope Study," The Journal of Clinical Endocrinology \& Metabolism, Vol. 89, No. 4, 2004, pp. 1801-1807. doi:10.1210/jc.2003-031474

[49] T. Elgzyri, et al., "The Effects of GH Replacement Therapy on Cardiac Morphology and Function, Exercise Capacity and Serum Lipids in Elderly Patients with GH De- 
ficiency," Clinical Endocrinology, Vol. 61, No. 1, 2004, pp. 113-122. doi:10.1111/j.1365-2265.2004.02080.x

[50] A. R. Hoffman, et al., "Growth Hormone (GH) Replacement Therapy in Adult-Onset GH Deficiency: Effects on Body Composition in Men and Women in a Double-Blind, Randomized, Placebo-Controlled Trial," The Journal of Clinical Endocrinology \& Metabolism, Vol. 89, No. 5, 2004, pp. 2048-2056. doi:10.1210/jc.2003-030346

[51] J. Bollerslev, et al., "Positive Effects of a Physiological Dose of GH on Markers of Atherogenesis: A PlaceboControlled Study in Patients with Adult-Onset GH Deficiency," European Journal of Endocrinology, Vol. 154, No. 4, 2006, pp. 537-543. doi:10.1530/eje.1.02125

[52] K. Chihara, et al., "Efficacy and safety of Growth Hormone $(\mathrm{GH})$ in the Treatment of Adult Japanese Patients with GH Deficiency: A Randomised, Placebo-Controlled Study," Growth Hormone \& IGF Research, Vol. 16, No. 2, 2006, pp. 132-142. doi:10.1016/j.ghir.2006.03.012

[53] C. Beauregard, et al., "Growth Hormone Decreases Visceral Fat and Improves Cardiovascular Risk Markers in Women with Hypopituitarism: A Randomized, PlaceboControlled Study," The Journal of Clinical Endocrinology \& Metabolism, Vol. 93, No. 6, 2008, pp. 2063-2071. doi:10.1210/jc.2007-2371

[54] K. Chihara, et al., "Efficacy and Safety of Individualized Growth Hormone Treatment in Adult Japanese Patients with Growth Hormone Deficiency," Growth Hormone \& IGF Research, Vol. 18, No. 5, 2008, pp. 394-403. doi:10.1016/j.ghir.2008.02.002

[55] A. Cittadini, et al., "Growth Hormone Deficiency in Patients with Chronic Heart Failure and Beneficial Effects of Its Correction," The Journal of Clinical Endocrinology \& Metabolism, Vol. 94, No. 9, 2009, pp. 3329-3336. doi:10.1210/jc.2009-0533

[56] K. Chihara, et al., "Dose-Dependent Changes in Body Composition during Growth Hormone (GH) Treatment in Japanese Patients with Adult GH Deficiency: A Randomized, Placebo-Controlled Trial," Growth Hormone \& IGF Research, Vol. 20, No. 3, 2010, pp. 205-211. doi:10.1016/j.ghir.2010.01.003

[57] P. Dutta, et al., "Effects of Short Term Growth Hormone Therapy in Adult Growth Hormone Deficiency," Journal of the Association of Physicians of India, Vol. 58, 2010, pp. 670-673.

[58] K. K. Miller, et al., "Growth Hormone Deficiency after Treatment of Acromegaly: A Randomized, Placebo-Controlled Study of Growth Hormone Replacement," The Journal of Clinical Endocrinology \& Metabolism, Vol. 95, No. 2, 2010, pp. 567-577. doi:10.1210/jc.2009-1611

[59] C. B. Newman, et al., "Moderate Doses of hGH (0.64 $\mathrm{mg} / \mathrm{d}$ ) Improve Lipids But Not Cardiovascular Function in GH-Deficient Adults with Normal Baseline Cardiac Function," The Journal of Clinical Endocrinology \& Metabolism, Vol. 96, No. 1, 2011, pp. 122-132. doi:10.1210/jc.2010-1204

[60] C. M. Florkowski, et al., "Low-Dose Growth Hormone Replacement Lowers Plasma Leptin and Fat Stores without Affecting Body Mass Index in Adults with Growth Hormone Deficiency," Clinical Endocrinology, Vol. 45,
No. 6, 1996, pp. 769-773. doi:10.1046/j.1365-2265.1996.830895.x

[61] S. A. Beshyah, et al., "Replacement Treatment with Biosynthetic Human Growth Hormone in Growth HormoneDeficient Hypopituitary Adults," Clinical Endocrinology, Vol. 42, No. 1, 1995, pp. 73-84.

doi:10.1111/j.1365-2265.1995.tb02601.x

[62] G. Johannsson, et al., "The Individual Responsiveness to Growth Hormone (GH) Treatment in GH-Deficient Adults Is Dependent on the Level of GH-Binding Protein, Body Mass Index, Age, and Gender," The Journal of Clinical Endocrinology \& Metabolism, Vol. 81, No. 4, 1996, pp. 1575-1581. doi:10.1210/jc.81.4.1575

[63] Y. E. Snel, et al., "Energy and Macronutrient Intake in Growth Hormone-Deficient Adults: The Effect of Growth Hormone Replacement," European Journal of Clinical Nutrition, Vol. 49, No. 7, 1995, pp. 492-500.

[64] J. Mesa, et al., "Growth Hormone Deficiency in Adults: Effects of Replacement Therapy on Body Composition and Health-Related Quality of Life," Medicina Clínica, Vol. 120, No. 2, 2003, pp. 41-46. doi:10.1157/13042257

[65] L. V. Hedges, "Distribution Theory for Glass's Estimator of Effect Size and Related Estimators," Journal of Educational and Behavioral Statistics, Vol. 6, 1981, pp. 107128. doi:10.3102/10769986006002107

[66] W. Cochran, "The Combination of Estimates from Different Experiments," Biometrics, Vol. 10, 1954, pp. 110129. doi: $10.2307 / 3001666$

[67] L. Sacca, "Heart Failure as a Multiple Hormonal Deficiency Syndrome," Circulation: Heart Failure, Vol. 2, No. 3, 2009, pp. 151-156. doi:10.1161/CIRCHEARTFAILURE.108.821892

[68] T. Rosen, et al., "Premature Mortality Due to Cardiovascular Disease in Hypopituitarism," The Lancet, Vol. 336, No. 8710,1990 , pp. 285-288. doi:10.1016/0140-6736(90)91812-O

[69] W. S. Cutfield, et al., "Incidence of Diabetes Mellitus and Impaired Glucose Tolerance in Children and Adolescents Receiving Growth-Hormone Treatment," The Lancet, Vol. 355, No. 9240, 2000, pp. 610-613. doi:10.1016/S0140-6736(99)04055-6

[70] S. Achar, et al., "Cardiac and Metabolic Effects of Anabolic-Androgenic Steroid Abuse on Lipids, Blood Pressure, Left Ventricular Dimensions, and Rhythm," American Journal of Cardiology, Vol. 106, No. 6, 2010, pp. 893-901. doi:10.1016/i.amjcard.2010.05.013

[71] A. Juul, et al., "Effects of Growth Hormone Replacement Therapy on IGF-Related Parameters and on the Pituitary-Gonadal Axis in GH-Deficient Males. A DoubleBlind, Placebo-Controlled Crossover Study," Hormone Research, Vol. 49, No. 6, 1998, pp. 269-278. doi: $10.1159 / 000023186$

[72] F. Darendeliler, et al., "Growth Hormone Increases Rate of Pubertal Maturation," Acta Endocrinologica, Vol. 122, No. 3, 1990, pp. 414-416.

[73] V. Y. Hayes, et al., "Recombinant Human Growth Hormone and Recombinant Human Insulin-Like Growth Factor I Diminish the Catabolic Effects of Hypogonadism in 
Man: Metabolic and Molecular Effects," The Journal of Clinical Endocrinology \& Metabolism, Vol. 86, No. 5, 2001, pp. 2211-2219. doi:10.1210/jc.86.5.2211

[74] E. R. Christ, et al., "Dynamics of Lipoprotein Metabolism in Adult Growth Hormone Deficiency," Journal of Endocrinological Investigation, Vol. 22, No. 5, 1999, pp. 16-21.

[75] A. F. Attanasio, et al., "Prevalence of Metabolic Syndrome in Adult Hypopituitary Growth Hormone (GH)Deficient Patients before and after GH Replacement," The Journal of Clinical Endocrinology \& Metabolism, Vol. 95, No. 1, 2010, pp. 74-81. doi:10.1210/jc.2009-1326

[76] M. C. Cenci, et al., "Effects of 5 Years of Growth Hormone (GH) Replacement Therapy on Cardiac Parameters and Physical Performance in Adults with GH Deficiency," Pituitary, Vol. 12, No. 4, 2009, pp. 322-329. doi:10.1007/s11102-009-0182-2

[77] G. Sesmilo, et al., "Cardiovascular Risk Factors in Acromegaly before and after Normalization of Serum IGF-I Levels with the GH Antagonist Pegvisomant," The Journal of Clinical Endocrinology \& Metabolism, Vol. 87, No. 4, 2002, pp. 1692-1699. doi:10.1210/jc.87.4.1692

[78] K. Caidahl, et al., "Cardiovascular and Renal Effects of Growth Hormone," Clinical Endocrinology, Vol. 40, No. 3, 1994, pp. 393-400. doi:10.1111/j.1365-2265.1994.tb03937.x

[79] R. C. Cuneo, et al., "Growth Hormone Treatment in Growth Hormone-Deficient Adults. II. Effects on Exercise Performance," Journal of Applied Physiology, Vol. 70, No. 2, 1991, pp. 695-700.

[80] J. L. Oliveira, et al., "Congenital Growth Hormone (GH) Deficiency and Atherosclerosis: Effects of GH Replacement in GH-Naive Adults," The Journal of Clinical Endocrinology \& Metabolism, Vol. 92, No. 12, 2007, pp. 4664-4670. doi:10.1210/jc.2007-1636

[81] D. N. O'Neal, et al., "The Effect of 3 Months of Recombinant Human Growth Hormone (GH) Therapy on Insulin and Glucose-Mediated Glucose Disposal and Insulin Secretion in GH-Deficient Adults: A Minimal Model Analysis," The Journal of Clinical Endocrinology \& Metabo- lism, Vol. 79, No. 4, 1994, pp. 975-983. doi:10.1210/jc.79.4.975

[82] J. U. Weaver, et al., "The Effect of Low Dose Recombinant Human Growth Hormone Replacement on Regional Fat Distribution, Insulin Sensitivity, and Cardiovascular Risk Factors in Hypopituitary Adults," The Journal of Clinical Endocrinology \& Metabolism, Vol. 80, No. 1, 1995, pp. 153-159. doi:10.1210/jc.80.1.153

[83] J. O. Johansson, et al., "Growth Hormone-Deficient Adults Are Insulin-Resistant," Metabolism, Vol. 44, No. 9, 1995, pp. 1126-1129. doi:10.1016/0026-0495(95)90004-7

[84] A. F. Attanasio, et al., "Prevalence and Incidence of Diabetes Mellitus in Adult Patients on Growth Hormone Replacement for Growth Hormone Deficiency: A Surveillance Database Analysis," The Journal of Clinical Endocrinology \& Metabolism, Vol. 96, No. 7, 2011, pp. 22552261. doi:10.1210/jc.2011-0448

[85] S. Neidert, et al., "Anterior Pituitary Axis Hormones and Outcome in Acute Ischaemic Stroke," Journal of Internal Medicine, Vol. 269, No. 4, 2011, pp. 420-432. doi:10.1111/j.1365-2796.2010.02327.x

[86] A. Selvamani, et al., "The Neurotoxic Effects of Estrogen on Ischemic Stroke in Older Female Rats Is Associated with Age-Dependent Loss of Insulin-Like Growth Factor-1," The Journal of Neuroscience, Vol. 30, No. 20, 2010, pp. 6852-6861. doi:10.1523/JNEUROSCI.0761-10.2010

[87] F. Pinto, et al., "Doping and Urologic Tumors," Urologia, Vol. 77, No. 2, 2010, pp. 92-99.

[88] C. A. Lissett, et al., "Timing of Onset of Growth Hormone Deficiency Is a Major Influence on Insulin-Like Growth Factor I Status in Adult Life," Clinical Endocrinology, Vol. 57, No. 1, 2002, pp. 35-40. doi:10.1046/j.1365-2265.2002.01556.x

[89] R. D. Murray, et al., "Influences on Quality of Life in GH Deficient Adults and Their Effect on Response to Treatment," Clinical Endocrinology, Vol. 51, No. 5, 1999, pp. 565-573. doi:10.1046/j.1365-2265.1999.00838.x 


\section{Supplementary Tables}

Supplementary Table 1. Summary of sensitivity analysis.

\begin{tabular}{|c|c|c|c|c|c|c|}
\hline Variable & $\begin{array}{l}\text { Study Excluded } \\
\text { (Reference) }\end{array}$ & $\begin{array}{c}\text { Population of Study } \\
\text { Excluded }\end{array}$ & Initial P-Value & $\begin{array}{c}\text { Post } \\
\text { P-Value }\end{array}$ & Initial ES & Post ES \\
\hline IGF1 & 64 & 165 & $<0.0001$ & $<0.0001$ & 6.90 & 7.34 \\
\hline IGFBP3 & 64 & 165 & 0.0002 & 0.0012 & 2.36 & 2.80 \\
\hline WHR & 64 & 165 & 0.0002 & 0.0008 & -2.79 & -3.42 \\
\hline LBM & 50 & 166 & 0.0002 & 0.001 & 1.15 & 1.14 \\
\hline FFM & 64 & 165 & $<0.0001$ & 0.0012 & 1.04 & 0.99 \\
\hline TRF & 54 & 116 & 0.1265 & 0.1761 & -3.67 & -0.31 \\
\hline TBW & 64 & 165 & 0.0001 & 0.0011 & 2.04 & 1.98 \\
\hline FM & 64 & 165 & $<0.0001$ & $<0.0001$ & -2.25 & -2.08 \\
\hline BMI & 64 & 165 & $<0.0001$ & 0.021 & -0.38 & -0.16 \\
\hline SBP & 32 & 163 & 0.3268 & 0.786 & -0.98 & -0.23 \\
\hline DBP & 32 & 163 & 0.4389 & 0.8039 & -0.68 & 0.12 \\
\hline HR & 43 & 64 & 0.1327 & 0.0044 & 0.70 & 1.03 \\
\hline SV & 59 & 30 & 0.5092 & $<0.0001$ & 0.28 & 0.72 \\
\hline LDL & 51 & 55 & $<0.0001$ & $<0.0001$ & -1.09 & -1.14 \\
\hline HDL & 51 & 55 & 0.032 & 0.0392 & 0.37 & 0.39 \\
\hline TChol & 32 & 163 & $<0.0001$ & $<0.0001$ & -0.83 & -0.82 \\
\hline TG & 32 & 163 & 0.4225 & 0.2136 & -0.14 & -0.21 \\
\hline ApoB & 23 & 40 & $<0.0001$ & 0.0009 & -0.76 & -0.96 \\
\hline CRP & 51 & 55 & 0.0284 & 0.0703 & -1.24 & -1.57 \\
\hline EAR & 21 & 36 & $<0.0001$ & 0.1621 & 0.23 & 0.21 \\
\hline FS & 49 & 31 & 0.4036 & 0.4106 & 0.44 & 0.44 \\
\hline LVM & 55 & 56 & 0.8633 & 0.1367 & 0.05 & 0.24 \\
\hline Fasting Insulin & 27 & 165 & $<0.0001$ & $<0.0001$ & 1.30 & 1.43 \\
\hline Fasting Glucose & 27 & 165 & 0.0144 & 0.0305 & 0.64 & 0.66 \\
\hline HgbA1c & 27 & 165 & 0.0155 & 0.0088 & 0.48 & 0.65 \\
\hline
\end{tabular}

ES: effect size.

Supplementary Table 2. Meta-analysis of studies by GH dose.

Low Dose GH $(<0.35 \mathrm{U} / \mathrm{kg} /$ week $)$

High Dose GH ( $\geq 0.35$ U/kg/week)

\begin{tabular}{ccccccccccc}
\hline Variable & \# Studies & \# Subjects & ES & P-Value & WMD (SD) & \# Studies & \# Subjects & ES & P-Value & WMD (SD) \\
\hline IGF1 & 17 & 949 & 6.51 & $<0.0001$ & $78.97(1.83) \mathrm{ng} / \mathrm{mL}$ & 2 & 52 & 9.97 & $<0.00001$ & $129.08(12.66) \mathrm{ng} / \mathrm{mL}$ \\
IGFBP3 & 5 & 547 & 2.36 & 0.0002 & $0.55(0.09) \mathrm{ng} / \mathrm{mL}$ & 0 & 0 & ND & ND & ND \\
WHR & 7 & 565 & -3.31 & 0.0001 & $-0.03(0.09)$ & 1 & 40 & ND & ND & ND \\
LBM & 11 & 505 & 1.36 & 0.0018 & $1.03(0.1) \mathrm{kg}$ & 4 & 240 & 0.67 & 0.0387 & $1.50(0.16) \mathrm{kg}$ \\
FFM & 6 & 469 & 1.04 & $<0.0001$ & $0.95(0.1) \mathrm{kg}$ & 0 & 0 & ND & ND & ND \\
TRF & 2 & 159 & -5.24 & 0.3053 & $-1.81(0.19) \mathrm{kg}$ & 1 & 24 & ND & ND & $-1.77(0.48) \mathrm{kg}$ \\
\hline
\end{tabular}




\begin{tabular}{|c|c|c|c|c|c|c|c|c|c|c|}
\hline TBW & 7 & 287 & 2.04 & 0.0001 & $0.92(0.09) \mathrm{L}$ & 0 & 0 & ND & ND & ND \\
\hline FM & 15 & 828 & -2.44 & $<0.0001$ & $-1.28(0.08) \mathrm{kg}$ & 2 & 34 & -0.88 & 0.0356 & $-2.47(0.37) \mathrm{kg}$ \\
\hline BMI & 10 & 412 & -0.38 & 0.0004 & $-0.05(0.1) \mathrm{kg} / \mathrm{m}^{2}$ & 0 & 0 & ND & ND & ND \\
\hline SBP & 4 & 326 & -1.82 & 0.0526 & $-2.54(0.15) \mathrm{mmHg}$ & 1 & 36 & ND & ND & $4.83(0.66) \mathrm{mmHg}$ \\
\hline DBP & 4 & 326 & -1.32 & 0.1298 & $-2.01(0.14) \mathrm{mmHg}$ & 1 & 36 & ND & ND & $1.89(0.4) \mathrm{mmHg}$ \\
\hline $\mathrm{HR}$ & 3 & 151 & 0.54 & 0.4115 & $0.39(0.16) \mathrm{BPM}$ & 2 & 56 & 1 & 0.2992 & $1.21(0.29) \mathrm{BPM}$ \\
\hline SV & 1 & 30 & ND & ND & ND & 2 & 44 & 0.72 & $<0.00001$ & $2.45(0.4) \mathrm{mL}$ \\
\hline LDL & 19 & 916 & -1.00 & $<0.0001$ & $-7.29(0.19) \mathrm{mg} / \mathrm{dL}$ & 4 & 123 & -1.67 & 0.0263 & $-13.36(0.87) \mathrm{mg} / \mathrm{dL}$ \\
\hline HDL & 17 & 758 & 0.36 & 0.0474 & $1.00(0.08) \mathrm{mg} / \mathrm{dL}$ & 4 & 123 & 0.48 & 0.4422 & $0.78(0.19) \mathrm{mg} / \mathrm{dL}$ \\
\hline TChol & 21 & 990 & -0.76 & $<0.0001$ & $-6.44(0.16) \mathrm{mg} / \mathrm{dL}$ & 5 & 133 & -1.24 & 0.0273 & $-11.34(0.67) \mathrm{mg} / \mathrm{dL}$ \\
\hline TG & 17 & 801 & -0.21 & 0.3054 & $-1.98(0.09) \mathrm{mg} / \mathrm{dL}$ & 4 & 123 & 0.13 & 0.7005 & $3.80(0.3) \mathrm{mg} / \mathrm{dL}$ \\
\hline ApoB & 1 & 18 & ND & ND & ND & 2 & 64 & -0.69 & $<0.00001$ & $-0.14(0.25) \mathrm{g} / \mathrm{L}$ \\
\hline CRP & 4 & 168 & -1.24 & 0.0284 & $-1.02(0.14) \mathrm{mg} / \mathrm{L}$ & 0 & 0 & ND & ND & ND \\
\hline EAR & 3 & 81 & 0.04 & 0.8892 & $-0.01(0.22)$ & 2 & 56 & 0.44 & 0.1036 & $0.07(0.27)$ \\
\hline FS & 4 & 101 & -0.3 & 0.0908 & $0.26(0.2) \%$ & 2 & 44 & 1.81 & 0.005 & $1.66(0.35) \%$ \\
\hline LVM & 3 & 106 & -0.27 & 0.5421 & $-2.55(0.26) \mathrm{g}$ & 3 & 80 & 0.35 & 0.2081 & $1.14(0.24) \mathrm{g}$ \\
\hline $\begin{array}{l}\text { Fasting } \\
\text { Insulin }\end{array}$ & 10 & 390 & 1.21 & 0.0001 & $1.62(0.12) \mu \mathrm{IU} / \mathrm{mL}$ & 2 & 64 & 1.65 & 0.145 & $1.69(0.29) \mu \mathrm{IU} / \mathrm{mL}$ \\
\hline $\begin{array}{l}\text { Fasting } \\
\text { Glucose }\end{array}$ & 11 & 588 & 0.71 & 0.0542 & $1.22(0.09) \mathrm{mg} / \mathrm{dL}$ & 4 & 240 & 0.42 & 0.0115 & $2.53(0.18) \mathrm{mg} / \mathrm{dL}$ \\
\hline HgbA1c & 6 & 280 & 0.61 & 0.0273 & $0.06(0.12) \%$ & 1 & 166 & ND & ND & $0.07(0.18) \%$ \\
\hline
\end{tabular}

ES: effect size; WMD: weighted mean difference; SD: standard deviation.

Supplementary Table 3. Meta-analysis of studies by gender.

\begin{tabular}{|c|c|c|c|c|c|c|c|c|c|c|}
\hline \multirow[b]{2}{*}{ Variable } & \multicolumn{3}{|c|}{$<\mathbf{5 0} \%$ Females } & \multicolumn{7}{|c|}{$\geq 50 \%$ Females } \\
\hline & \# Studies & \# Subjects & ES & P-Value & WMD (SD) & \# Studies & \# Subjects & ES & P-Value & WMD (SD) \\
\hline IGF1 & 12 & 788 & 7.93 & $<0.0001$ & $82.92(2.11) \mathrm{ng} / \mathrm{mL}$ & 7 & 213 & 5.15 & $<0.0001$ & $76.89(3.73) \mathrm{ng} / \mathrm{mL}$ \\
\hline IGFBP3 & 5 & 547 & 2.36 & 0.0002 & $0.55(0.09) \mathrm{ng} / \mathrm{mL}$ & 0 & 0 & ND & ND & ND \\
\hline WHR & 5 & 506 & -3.96 & 0.0002 & $-0.03(0.09)$ & 3 & 99 & -1.27 & 0.1755 & $-0.01(0.2)$ \\
\hline LBM & 9 & 585 & 1.47 & 0.0013 & $1.16(0.09) \mathrm{kg}$ & 6 & 160 & 0.70 & 0.0018 & $1.22(0.17) \mathrm{kg}$ \\
\hline FFM & 4 & 396 & 1.31 & $<0.0001$ & $1.07(0.11) \mathrm{kg}$ & 2 & 73 & 0.47 & 0.2658 & $0.30(0.24) \mathrm{kg}$ \\
\hline TRF & 3 & 183 & -3.67 & 0.1265 & $-1.80(0.18) \mathrm{kg}$ & 0 & 0 & ND & ND & ND \\
\hline TBW & 6 & 280 & 2.26 & 0.0001 & $0.90(0.09) \mathrm{L}$ & 1 & 7 & ND & ND & $1.53(0.63) \mathrm{L}$ \\
\hline FM & 11 & 683 & -2.64 & $<0.0001$ & $-1.38(0.09) \mathrm{kg}$ & 6 & 179 & -1.53 & 0.0021 & $-1.26(0.16) \mathrm{kg}$ \\
\hline BMI & 8 & 384 & -0.13 & 0.0997 & $-0.05(0.10) \mathrm{kg} / \mathrm{m}^{2}$ & 2 & 28 & -0.08 & 0.1726 & $0.01(0.38) \mathrm{kg} / \mathrm{m}^{2}$ \\
\hline SBP & 4 & 326 & -1.82 & 0.0526 & $-2.54(0.15) \mathrm{mmHg}$ & 1 & 36 & $\mathrm{ND}$ & ND & $4.83(0.66) \mathrm{mmHg}$ \\
\hline DBP & 4 & 326 & -1.32 & 0.1298 & $-2.01(0.14) \mathrm{mmHg}$ & 1 & 36 & ND & ND & $1.89(0.4) \mathrm{mmHg}$ \\
\hline $\mathrm{HR}$ & 4 & 171 & 0.87 & 0.1451 & 0.69 (0.16) BPM & 1 & 36 & ND & ND & $0.25(0.34) \mathrm{BPM}$ \\
\hline SV & 3 & 74 & 0.28 & 0.5092 & $-0.49(19.02) \mathrm{mL}$ & 0 & 0 & ND & ND & ND \\
\hline LDL & 11 & 659 & -1.22 & 0.0001 & $-9.05(0.28) \mathrm{mg} / \mathrm{dL}$ & 12 & 398 & -0.98 & 0.0003 & $-6.55(0.26) \mathrm{mg} / \mathrm{dL}$ \\
\hline HDL & 11 & 629 & 0.32 & 0.0666 & $0.90(0.09) \mathrm{mg} / \mathrm{dL}$ & 10 & 270 & 0.44 & 0.2605 & $1.14(0.14) \mathrm{mg} / \mathrm{dL}$ \\
\hline
\end{tabular}


Continued

\begin{tabular}{ccccccccccc}
\hline TChol & 14 & 669 & -0.83 & $<0.0001$ & $-6.86(0.19) \mathrm{mg} / \mathrm{dL}$ & 12 & 428 & -0.83 & 0.0032 & $-7.55(0.29) \mathrm{mg} / \mathrm{dL}$ \\
TG & 11 & 695 & -0.05 & 0.8002 & $-1.07(0.08) \mathrm{mg} / \mathrm{dL}$ & 9 & 239 & -0.27 & 0.4903 & $-1.68(0.15) \mathrm{mg} / \mathrm{dL}$ \\
ApoB & 1 & 24 & $\mathrm{ND}$ & $\mathrm{ND}$ & $-0.19(0.41) \mathrm{g} / \mathrm{L}$ & 2 & 58 & -0.87 & 0.0065 & $-0.10(0.26) \mathrm{g} / \mathrm{L}$ \\
CRP & 2 & 95 & -0.44 & 0.0005 & $-0.99(0.17) \mathrm{mg} / \mathrm{L}$ & 2 & 73 & -2.15 & 0.1270 & $-1.10(0.25) \mathrm{mg} / \mathrm{L}$ \\
EAR & 3 & 81 & 0.27 & 0.1135 & $0.01(0.22)$ & 2 & 56 & 0.21 & 0.0580 & $0.03(0.27)$ \\
FS & 5 & 125 & 0.67 & 0.2964 & $0.87(0.19) \%$ & 1 & 20 & $\mathrm{ND}$ & $\mathrm{ND}$ & $-0.45(0.45) \%$ \\
LVM & 5 & 150 & 0.10 & 0.7894 & $-0.48(0.17) \mathrm{g}$ & 1 & 36 & $\mathrm{ND}$ & $\mathrm{ND}$ & $3(0.49) \mathrm{g}$ \\
Fasting Insulin & 6 & 297 & 1.23 & 0.0071 & $1.63(0.13) \mu \mathrm{IU} / \mathrm{mL}$ & 6 & 157 & 1.39 & 0.0023 & $1.61(0.18) \mu \mathrm{IU} / \mathrm{mL}$ \\
Fasting Glucose & 9 & 687 & 0.91 & 0.0156 & $2.02(0.10) \mathrm{mg} / \mathrm{dL}$ & 5 & 141 & 0.36 & 0.3113 & $0.68(0.17) \mathrm{mg} / \mathrm{dL}$ \\
HgbA1c & 4 & 389 & 0.34 & 0.1474 & $0.05(0.11) \%$ & 3 & 57 & 0.74 & 0.0077 & $0.10(0.27) \%$ \\
\hline
\end{tabular}

ES: effect size; WMD: weighted mean difference; SD: standard deviation.

Supplementary Table 4. Meta-analysis of studies by study duration.

\begin{tabular}{|c|c|c|c|c|c|c|c|c|c|c|}
\hline \multirow[b]{2}{*}{ Variable } & \multicolumn{2}{|c|}{$<6$ months } & \multicolumn{8}{|c|}{$\geq 6$ months } \\
\hline & \# Studies & \# Subjects & ES & P-Value & WMD (SD) & \# Studies & \# Subjects & ES & P-Value & WMD (SD) \\
\hline IGF1 & 3 & 56 & 9.04 & 0.0307 & $106.6(10.08) \mathrm{ng} / \mathrm{mL}$ & 16 & 945 & 6.75 & $<0.0001$ & $80.11(1.86) \mathrm{ng} / \mathrm{mL}$ \\
\hline IGFBP3 & 0 & 0 & ND & ND & ND & 5 & 547 & 2.36 & 0.0002 & $0.55(0.09) \mathrm{ng} / \mathrm{mL}$ \\
\hline WHR & 1 & 20 & ND & ND & ND & 7 & 585 & -3.25 & 0.0001 & $-0.03(0.08)$ \\
\hline LBM & 5 & 80 & 0.43 & 0.0001 & $1.52(0.26) \mathrm{kg}$ & 10 & 665 & 1.44 & 0.0003 & $1.13(0.09) \mathrm{kg}$ \\
\hline FFM & 0 & 0 & ND & ND & ND & 6 & 469 & 1.04 & $<0.0001$ & $0.95(0.10) \mathrm{kg}$ \\
\hline TRF & 1 & 24 & ND & ND & ND & 2 & 159 & -5.24 & 0.3053 & $-1.81(0.19) \mathrm{kg}$ \\
\hline TBW & 1 & 13 & ND & ND & ND & 6 & 573 & 2.26 & 0.0001 & $0.9(0.09) \mathrm{L}$ \\
\hline FM & 4 & 76 & -0.47 & 0.0082 & $-1.51(0.26) \mathrm{kg}$ & 13 & 786 & -2.74 & $<0.0001$ & $-1.34(0.08) \mathrm{kg}$ \\
\hline BMI & 3 & 58 & 0.31 & $<0.0001$ & $0.08(0.26) \mathrm{kg} / \mathrm{m}^{2}$ & 7 & 354 & -0.28 & $<0.0001$ & $-0.07(0.11) \mathrm{kg} / \mathrm{m}^{2}$ \\
\hline SBP & 0 & 0 & ND & ND & ND & 5 & 362 & -0.98 & 0.3268 & $-1.77(0.13) \mathrm{mmHg}$ \\
\hline DBP & 0 & 0 & ND & ND & ND & 5 & 362 & -0.68 & 0.4389 & $-1.6(0.12) \mathrm{mmHg}$ \\
\hline HR & 0 & 0 & ND & ND & ND & 5 & 207 & 0.70 & 0.1327 & $0.61(0.14) \mathrm{BPM}$ \\
\hline SV & 0 & 0 & ND & ND & ND & 3 & 74 & 0.28 & 0.5092 & $-0.49(0.24) \mathrm{mL}$ \\
\hline LDL & 5 & 89 & -1.66 & $<0.0001$ & $-11(0.86) \mathrm{mg} / \mathrm{dL}$ & 18 & 792 & -0.94 & $<0.0001$ & $-7.77(0.2) \mathrm{mg} / \mathrm{dL}$ \\
\hline HDL & 5 & 89 & 0.46 & 0.1144 & $0.76(0.22) \mathrm{mg} / \mathrm{dL}$ & 16 & 950 & 0.36 & 0.0740 & $1.00(0.08) \mathrm{mg} / \mathrm{dL}$ \\
\hline TChol & 5 & 89 & -1.07 & $<0.0001$ & $-7.75(0.63) \mathrm{mg} / \mathrm{dL}$ & 21 & 1034 & -0.81 & $<0.0001$ & $-7.04(0.17) \mathrm{mg} / \mathrm{dL}$ \\
\hline TG & 4 & 76 & -0.06 & 0.9092 & $0.69(0.24) \mathrm{mg} / \mathrm{dL}$ & 17 & 848 & -0.16 & 0.4166 & $-1.39(0.08) \mathrm{mg} / \mathrm{dL}$ \\
\hline ApoB & 1 & 18 & ND & ND & ND & 2 & 64 & -0.69 & $<0.0001$ & $-0.14(0.25) \mathrm{g} / \mathrm{L}$ \\
\hline CRP & 0 & 0 & ND & ND & ND & 4 & 168 & -1.24 & 0.0284 & $-1.02(0.14) \mathrm{mg} / \mathrm{L}$ \\
\hline EAR & 0 & 0 & ND & ND & ND & 5 & 137 & 0.23 & $<0.0001$ & $0.02(0.17)$ \\
\hline FS & 0 & 0 & ND & ND & ND & 6 & 145 & 0.44 & 0.4036 & $0.68(0.17) \%$ \\
\hline LVM & 0 & 0 & ND & ND & ND & 6 & 186 & 0.05 & 0.8633 & $-0.96(0.16) \mathrm{g}$ \\
\hline Fasting Insulin & 4 & 68 & 1.33 & 0.0006 & $1.95(0.29) \mu \mathrm{IU} / \mathrm{mL}$ & 8 & 386 & 1.28 & 0.0013 & $1.57(0.12) \mu \mathrm{IU} / \mathrm{mL}$ \\
\hline Fasting Glucose & 3 & 62 & -0.19 & 0.8326 & $0.61(0.26) \mathrm{mg} / \mathrm{dL}$ & 12 & 766 & 0.83 & 0.0026 & $1.69(0.09) \mathrm{mg} / \mathrm{dL}$ \\
\hline HgbA1c & 2 & 27 & 1.21 & $<0.0001$ & $0.13(0.4) \%$ & 5 & 419 & 0.34 & 0.0864 & $0.06(0.10) \%$ \\
\hline
\end{tabular}

ES: effect size; WMD: weighted mean difference; SD: standard deviation. 
Supplementary Table 5. Meta-analysis of studies by subject age.

\begin{tabular}{|c|c|c|c|c|c|c|c|c|c|c|}
\hline \multicolumn{3}{|c|}{$<40$ years } & \multicolumn{8}{|c|}{$\geq 40$ years } \\
\hline Variable & \# Studies & \# Subjects & ES & P-Value & WMD (SD) & \# Studies & \# Subjects & ES & P-Value & WMD (SD) \\
\hline IGF1 & 5 & 348 & 3.92 & $<0.0001$ & $86.58(3.28) \mathrm{ng} / \mathrm{mL}$ & 14 & 653 & 8.44 & $<0.0001$ & $78.90(2.22) \mathrm{ng} / \mathrm{mL}$ \\
\hline IGFBP3 & 2 & 238 & 1.06 & 0.0002 & $0.61(0.13) \mathrm{ng} / \mathrm{mL}$ & 3 & 309 & 3.33 & 0.0119 & $0.5(0.12) \mathrm{ng} / \mathrm{mL}$ \\
\hline WHR & 2 & 181 & -0.91 & 0.0031 & $-0.02(0.15)$ & 6 & 424 & -3.91 & 0.0007 & $-0.03(0.1)$ \\
\hline LBM & 5 & 287 & 2.15 & 0.0208 & $1.12(0.13) \mathrm{kg}$ & 10 & 458 & 0.77 & 0.0000 & $1.22(0.11) \mathrm{kg}$ \\
\hline FFM & 1 & 165 & ND & ND & ND & 5 & 279 & 0.99 & 0.0012 & $0.92(0.14) \mathrm{kg}$ \\
\hline TRF & 2 & 140 & -5.48 & 0.2599 & $-2.3(0.22) \mathrm{kg}$ & 1 & 43 & ND & ND & ND \\
\hline TBW & 1 & 165 & ND & ND & ND & 6 & 421 & 1.98 & 0.0011 & $0.88(0.1) \mathrm{L}$ \\
\hline FM & 7 & 468 & -2.52 & 0.0024 & $-1.4(0.10) \mathrm{kg}$ & 10 & 329 & -2.04 & 0.0002 & $-1.29(0.11) \mathrm{kg}$ \\
\hline BMI & 2 & 181 & -0.09 & 0.9131 & $0.08(0.15) \mathrm{kg} / \mathrm{m}^{2}$ & 8 & 371 & -0.23 & 0.0019 & $-0.15(0.13) \mathrm{kg} / \mathrm{m}^{2}$ \\
\hline SBP & 0 & 0 & ND & ND & ND & 5 & 362 & -0.98 & 0.3268 & $-1.77(0.13) \mathrm{mmHg}$ \\
\hline DBP & 0 & 0 & ND & ND & ND & 5 & 362 & -0.68 & 0.4389 & $-1.6(0.12) \mathrm{mmHg}$ \\
\hline HR & 0 & 0 & ND & ND & ND & 5 & 207 & 0.70 & 0.1327 & $0.61(0.14) \mathrm{BPM}$ \\
\hline SV & 1 & 24 & ND & ND & ND & 2 & 50 & 0.05 & 0.9342 & $-1.69(0.33) \mathrm{mL}$ \\
\hline LDL & 7 & 420 & -0.63 & 0.0235 & $-7.18(0.28) \mathrm{mg} / \mathrm{dL}$ & 16 & 619 & -1.30 & $<0.0001$ & $-8.64(0.27) \mathrm{mg} / \mathrm{dL}$ \\
\hline HDL & 5 & 259 & 0.43 & 0.3172 & $1.44(0.14) \mathrm{mg} / \mathrm{dL}$ & 16 & 622 & 0.37 & 0.0643 & $0.78(0.08) \mathrm{mg} / \mathrm{dL}$ \\
\hline TChol & 8 & 427 & -0.48 & 0.0184 & $-7.66(0.29) \mathrm{mg} / \mathrm{dL}$ & 18 & 696 & -1.02 & $<0.0001$ & $-6.78(0.19) \mathrm{mg} / \mathrm{dL}$ \\
\hline $\mathrm{TG}$ & 5 & 259 & 0.19 & 0.4331 & $-4.29(0.23) \mathrm{mg} / \mathrm{dL}$ & 16 & 665 & -0.27 & 0.2403 & $-0.11(0.08) \mathrm{mg} / \mathrm{dL}$ \\
\hline ApoB & 1 & 24 & ND & ND & ND & 2 & 58 & -0.87 & 0.0065 & $-0.1(0.26) \mathrm{g} / \mathrm{L}$ \\
\hline CRP & 0 & 0 & ND & ND & ND & 4 & 168 & -1.24 & 0.0284 & $-1.02(0.14) \mathrm{mg} / \mathrm{L}$ \\
\hline EAR & 1 & 20 & ND & ND & ND & 4 & 117 & 0.24 & $<0.0001$ & $0.02(0.19)$ \\
\hline FS & 2 & 44 & 0.39 & 0.636 & $0.34(0.3) \%$ & 4 & 101 & 0.50 & 0.5578 & $0.83(0.21) \%$ \\
\hline LVM & 1 & 24 & ND & ND & $5(0.83) \mathrm{g}$ & 5 & 162 & -0.06 & 0.8574 & $-1.85(0.19) \mathrm{g}$ \\
\hline Fasting Insulin & 2 & 189 & 0.57 & 0.0618 & $1.76(0.17) \mu \mathrm{IU} / \mathrm{mL}$ & 10 & 265 & 1.53 & 0.0001 & $1.53(0.14) \mu \mathrm{IU} / \mathrm{mL}$ \\
\hline Fasting Glucose & 4 & 215 & 0.32 & 0.2393 & $0.38(0.13) \mathrm{mg} / \mathrm{dL}$ & 11 & 613 & 0.78 & 0.0299 & $2.12(0.11) \mathrm{mg} / \mathrm{dL}$ \\
\hline HgbA1c & 1 & 165 & ND & ND & ND & 6 & 281 & 0.65 & 0.0088 & $0.09(0.13) \%$ \\
\hline
\end{tabular}

ES: effect size; WMD: weighted mean difference; SD: standard deviation. 